\title{
CRITÉRIOS PARA CALAGEM EM SOLOS DO ESTADO DE SÃO PAULO
}

\author{
JOSÉ ANTONIO QUAGGIO
}

Orientador: PROF. EURÍPEDES MALAVOLTA

Dissertaçāo apresentada à Escola Superior de Agricultura "Luiz de Queiroz", da Universidade de São Paulo, para obtençāo do título de mestre em Agronomia, Área de Concentração Solos e Nutriçāo de Plantas.

P I R A C I C A B A

Estado de São Paulo - Brasil Janeiro - 1983 
Aos meus pais, Durval e Thereza pelos esforços dedicados a minha educação

$$
\text { ofereço }
$$

A minha esposa Mônica e ao Frederico

dedico 


\section{AGRADECIMENTOS}

Ao prof. Dr. Euripedes Malavolta, pelos ensina= mentos, orientação e atenção a nós dedicada.

Ao Pesquisador Científico Dr. Bernardo van Raij pelo incentivo e colaboração constante durante a execução des te trabalho.

Ao Pesquisador Cientifico Dr. Otävio Antonio de Camargo, pelas sugestões apresentadas.

Ao Enge Agro Marcelo B. Paes de Camargo, pelo auxílio no cãlculo das equações de regressão.

$\bar{A}$ Senhora Maria Eunice de Lucas Pereira pelo tra balho de datilografià

Ao Instituto Agronômico do Estado de são Paulo, pelas facilidades concedidas e pelo agradāvel local de trabalho.

Ao Conselho Nacional de Desenvolvimento Cientifico e Tecnológico (CNPq) pelo apoio financeiro, através da concessão de bolsa de pesquisa. 
Păgina

RESUMO $\ldots \ldots \ldots \ldots \ldots \ldots \ldots \ldots \ldots \ldots \ldots \ldots \ldots \ldots \ldots \ldots \ldots$

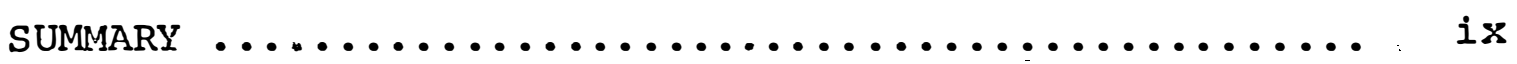

1. INTRODUÇÃo $\ldots \ldots \ldots \ldots \ldots \ldots \ldots \ldots \ldots \ldots \ldots \ldots$

2. REVISÃo DE LITERATURA $\ldots \ldots \ldots \ldots \ldots \ldots \ldots \ldots \ldots \ldots$

2.1 Natureza da acidez do solo .............. 4

2.2 Mētodos de recomendação de calagem ........ 12

2.2.1 Métodos baseados em curvas de titulação potenciométrica ............. 12

2.2.2 Métodos baseados no decréscimo do $\mathrm{pH}$ de soluções tampão .............. 13

2.2.3 Método baseado no teor de aluminio tro

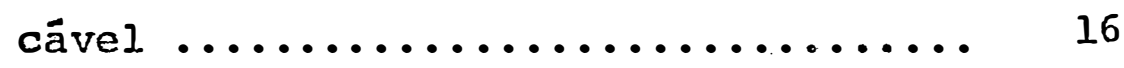

2.2.4 Métodos baseados na correlação entre o pH e saturação de bases ........... 17

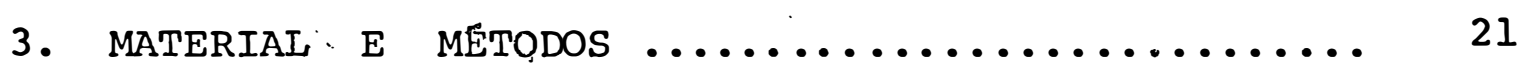

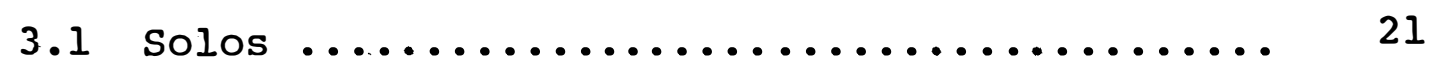

3.1 .1 Descrição dos solos estudados ....... 21

3.1.2 Preparo das amostras de terra ....... 23

3.2 Determinações de laboratōrio .............. 24

3.2.1 Matēria orgânica ................. 24

$3.2 .2 \mathrm{pH}$ em água e em solução de $\mathrm{CaCl}_{2} 0,01 \mathrm{M} \quad 24$

3.2.3 pH de equilíbrio da solução tampão com o solo ......................... 25

3.2.3.1 Composição e preparo da solução tampão ............... 25

3.2.3.2 Procedimento ........... 26 
Página

3.2.4 Cátions trocáveis ............. 27

3.2.5 H + Al pelo método da extração com acetato de cálcìo ................ 28

3.2 .6 Teor de argila $\ldots \ldots \ldots \ldots \ldots \ldots \ldots \ldots 28$

3.3 Cálculo da soma de bases, capacidade de troca de cátions e saturação de bases no solo .. 29

4. RESUltados E DISCUSSÃo $\ldots \ldots \ldots \ldots \ldots \ldots \ldots \ldots . \ldots \ldots$

4.1 Caracteristicas gerais dos solos .......... 31

4.1.1 Capacidade tampão das amostras estuda das ............................ 33

4.2 Determinações de $\mathrm{pH} \ldots \ldots \ldots \ldots \ldots \ldots \ldots \ldots . . \ldots \ldots$

4.3 Titulação potenciométrica da solução tampão SMP com diversos ácidos e solos .......... 40

4.4 Relação entre a acidez potencial do solo e o pH da solução tampão $\operatorname{SMP} \ldots \ldots \ldots \ldots \ldots \ldots \ldots . . . .42$

4.5 Determinação dos teores de $\mathrm{H}+\mathrm{Al}$ do solo através de leitura potenciométrica do $\mathrm{pH}$ SMP..

4.6 Relações entre $\mathrm{p} \mathrm{pH}$ e cátions trocảveis do solo ............................ 47

4.6.1 Estabelecidas com base na CTC a pH 7,0 47

4.6.2 Estabelecidas com base na CTC efetiva.

4.7 Evolução das förmulas para o cálculo da calagem com base na saturação de bases do solo ..

4.8 Necessidade de calagem determinada por diversos métodos .......................... 59

5. CONCLUSÕES $\ldots \ldots \ldots \ldots \ldots \ldots \ldots \ldots \ldots \ldots \ldots \ldots \ldots \ldots \ldots$

6. IITERATURA CITADA $\ldots \ldots \ldots \ldots \ldots \ldots \ldots \ldots \ldots \ldots \ldots$ 


\title{
CRITÉrios PARA CALAGEM EM SOLOS DO ESTADO DE SĀO PAULO
}

\author{
José Antonio Quaggio
}

Orientador : Prof. Euripedes Malavolta

RESUMO

o presente trabalho foị desenvolvido com os obje tivos de caracterizar-se a acidez de solos representativos do Estado de São Paulo e propor uma técnica de análise de solo pa ra a recomendação de calagem dotada de fundamentos teóricos, flexível a.fim de permitir o câlculo das doses de calcário, de acordo com as exigências das culturas e ajustada às condições dos laboratörios de rotina de análise de solo. Para tanto, fez-se una revisão de literatura procurando-se a evolução histórica dos conceitos ligados a acidez dos solos e dos principais mëtodos de recomendação de calagem. Para facilitar a organização da revisão, os mëtodos foram agrupados segundo os principios analiticos.

Vinte e seis amostras pertencentes äs principais unidades de mapeamento de solos do Estado de São Paulo foram 
coletadas, utilizando-se como critérios de seleção a representatividade em relação aos solos do Estado, ampla variação nos teores de argila, matēria orgânica, aluminio e bases trocāveis, com o propósito de se obter uma série de solo com grande variação na cap̉acidade tampão.

Como resultados, encontrou-se que a capacidade de troca de cations (CTC) desses solos depende principalmente da fração orgânica, enquanto que a contribuição da fração mine ral é modesta. Por conseguinte, a acidez potencial deles è oriunda principalmente da dissociação de grupos finncionais da matéria orgânica, uma vez que, os teores de alumînio trocável são baixos, com um teor médio da ordem de $0,83 \mathrm{meq} / 100 \mathrm{~cm}^{3}$ de terra, e sempre bem menores do que os teores de hidrogênio.

Desenvolveu-se uma técnica para a determinação

de $\mathrm{H}+\mathrm{Al}$ em amostras de solo, que consiste em ler potenciometricamente $\circ \mathrm{pH}$ de equilỉbrio da solução tampão de Shoemakex, Mclean e Pratt (SMP) com acidez potencial do solo. Os teores de $\mathrm{H}+\mathrm{Al}$ são obtidos através de uma equação de regressão cal. culada com os valores do $\mathrm{pH}$ de equilíbrio e os teores de $\mathrm{H}+$ Al, determinados na série de solos em estudo pelo método da ex tração com solução normal de acetato de cálcio a pH 7,0. O mẹ todo: desenvolvido além de ser mais rápido e portanto... mais adaptado às condições dos laboratörios de rotina de análise de solo, possue ainda melhor reprodutibilidade do que o método tí tulométrico.

Foram obtidas correlações entre o pH determinado 
em água e em solução de cloreto de cálcio 0,01M com o grau de saturação de bases do solo. As equações de regressão obtidas são praticamente idênticas a outras equaçoes de regressão, cal culadas anteriormente para os solos do mesmo Estado. Entretan to, cabe ressaltar que o uso do pH determinado em solução de $\mathrm{CaCl}_{2}$ 0,01M torna essa correlação ainda mais estreita.

Para o cälculo da necessidade de calagem com base na correlação entre $\circ \mathrm{pH}$ e saturação de bases foi desenvolvida uma nova förmula, na qual, a necessidade de calagen è diretamente proporcional à capacidade de troca de cätions, em condiçōes de igualiade de saturação de bases no solo. 


\title{
SOIL LIMING CRITERIA FOR SOILS OF. THE STATE OF SĀO PAULO
}

\author{
Josē Antonio Quaggio
}

Adviser : Prof. Eurỉpedes Malavolta

SUPMARY

This work was carried out in order to characterize the acidity of representative soils from são Paulo, Brazil and to develop a method for detexmination of lime. requirement adapted to routine laboratories. A review of the literature about the evolution of concepts on the nature of soil acidity and about, the methods for determining lime requirement was made.

Twenty six surface soil samples from the main taxonomy units were obtained for this research. The solls were chosen to represent the axea of the state of são Paulo as well as to provide considerable spread of properties related to the buffering capacity such as clay, organic matter and exchangeable aluminum contents.

In the soils studied, the cation exchange capacity depends mainly on the organic mather, whtle the 
contribution of mineral fraction is small. Therefore the potential acidity $(\mathrm{H}+\mathrm{Al})$ is due largely to the dissociation of acidic groups from the organic matter, since the exchangeable aluminum content is low, with average values of $0.83 \mathrm{meq} / 100 \mathrm{~cm}^{3}$ of soil, being always much smaller than the hydrogen content.

A method for determining $H$. Al was developed it consistes in the potentiometric reading of the equilibrium $\mathrm{pH}$ of the SMP buffer solution with soil. The $\mathrm{H}+\mathrm{Al}$ content is evaluated from a regression equation calculated with the data of $\mathrm{pH}_{\mathrm{SMP}}$ and corresponding $\mathrm{H}+\mathrm{Al}$ values, which wexe determined by the neutral calcium acetate method. The new method is simple, accurate and gives more reproducible results than the calcium acetate method.

With the same soil samples a correlation between $\mathrm{pH}$ and degree of base saturation was calculated and the regression equation thereof was similar to those presented in other papers with. soils from same state. The determination of soil pH in $0.01 \mathrm{M} \mathrm{CaCl} 2$ is more accurate and yields closer correlations with base saturation when compared with those calculated with $\mathrm{pH}$ determined in water. The consistency of this correlation for the são Paulo state soils condition provides reliance necessary to use it as criterion for the determination of the lime requirement. For this reason a new formula was derived for the calculation of lime requirement, based on the CEC and base saturation of the soil sample. 


\section{INTRODUÇÃO}

A necessidade de aplicação de calcário para a co rreção de características indesejāveis de alguns solos na produção agrỉcola, já era reconhecida antes da era cristã, onde os gregos e romanos aplicavam "margas" aos seus solos, para conseguirem aumento de produtividade das culturas. No Brasil, o uso de calcário tem proporcionado o aumento da produção agro pecuāria, permitindo a expansão da fronteira agrícola, principalmente em áreas sob vegetação de cerrados, bem como, pelo au mento da produtividade das culturas em solos cultivados que so freram 0 processo de acidificação.

Entretanto, o sucesso da aplicação de calcārio depende do conhecimento prévio das respostas das diferentes culturas à calagem e de métodos de análise de solo capazes de determinar a quantidade de calcärio necessária para suprir as exigências das plantas. As primeiras tentativas de medir a ne cessidade de calagem com base na análise de solo surgiram no 
final do século XIX, e desde então, tem recebído a atenção de muitos pesquisadores, o que tem proporcionado uma evolução con siderável nos conhecimentos da natureza da acidez dos solos. No Brasil, antes de 1965, os mëtodos de recomendação de calagèm usados na prätica eram quase sempre, baseados apenas no $\mathrm{pH}$ e no teor de matéria orgânica dos solos apesar, de já existirem métodos modernos publicados (PAIVA NETO . et alii, 1947; VETTORI, 1948 e CATANI \& GALLO, 1955). Após 1965, com a divulgação do critério do aluminnio trocável por COLEMAN et alii (1958) e KAMPRATH (1970) a recomendação c?a calagem pas sou a ser feita por esse.critério na maioria dos estados brasí leiros, com exceção dos Estados do Rio Grande do Sul e Santa Catarina que optaram pelo método SMP.

Esse método caracteriza-se por nivelar as culturas como igualmente exigentes em calcärio e por recomendar pequenas quantidades desse corretivo. Isso fez com que surgisse um outro critério complementar que procura garantir os teores de $\mathrm{Ca}^{2+}+\mathrm{Mg}^{2+}$ valores de 2 ou $3 \mathrm{meq} / 100 \mathrm{~cm}^{3}$ de terra, conforme a cultura, caso a recomendáção feita para neutralizar o alumínio seja insuficiente para garantir tais valores.

Experimentos mais recentes conduzidos no Estado de São Paulo têm mostrado que a recomendação de calagem feita pelo critério do alumínio trocável, é insuficiente para suprir as exigências das culturas e alcançar o máximo retorno econômi co para o agricultor. 
Esses fatos serviram de motivação para este estudo que teve por objetivos: a) caracterizar a acidez de solos representativos do Estado de São Paulo; b) propor técnica de determinação da necessidade de calagem dotada de fundamentos teóricos e adaptável às condições dos laboratórios de rotina para.fins de avaliação da fertilidade dos solos. 


\section{REVISÃO DE LITERATURA}

\subsection{NATUREZA DA ACIDEZ DO SOLO}

No final do século passado, todo solo que tornas se o papel de tornassol vermelho era considerado ácido. Na mesma época, começaram as descrições dos mêtodos quantitativos paxa a determinação da acidez do solo e recomendação de calagem. o primeiro deles, talvez o mais antigo, descrito por WHEELER et alii (1900) consistia em determinar os teores de "ācidos húmicos livres", mediante a extração com hidrôxido de amônio e posterior precipitação com ácido cloridrico. Como se pode notar à fração orgâniça era atribuída a acidez do solo e o hidrogênio era o único ín responsảvel por essa acidez. Com a publicação do trabalho de VEITCH (1902) outro método foi des crito e baseava-se em uma curva de titulação do solo com hidrō xido de cálcio, na qual o ponto de neutralidade era verificado pela viragem da fenolftaleína. VEITCH (1904) em outro trabalho, às vezes confundido com o anterior, observou, pela prime 
ra vez, a presença do Ion alumínio em extratos de solos com baixos teores de matēria orgânica. Esses extratos foram obtị dos por meio de lavagens sucessivas com NaCl o que levou o au tor a sugerir uma possível reação de troca do alumỉnio pelo sódio, atribuindo a acidez do solo à sua fração mineral. Esses resultados, apesar de terem sido contestados até por volta de 1953 pela comunidade científica norte-americana, já haviam sido comprovados no trabalho clássico de DAIKUHARA(1914), citado por VAGELER (1932).

Esses conceitos; foram introduzidos no Brasil por volta de 1932, com o livro do fundador da antiga Seção de Solos do Instituto Agronômico (VAGELER, 1932). Na década de trinta, em São Paulo, o método de DAIKUHARA (1914) já era utilizado com algumas modificações nos levantamentos de solos e serviu de base para o trabalho clássico realizado no Instituto Agronômico do Sul por ARAUJo (1949), sobre a influência do alu mínio trocável no "crestamento do trigo".

Em 1915, o conceito de pH foi aplicado na ciência do solo. Os primeiros resultados mostraram que vários solos apresentavam valores baixos de $\mathrm{pH}$, mesmo antes de serem tratados com soluçōes salinas. Esses valores baixos de $\mathrm{pH}$ foram interpretados de várias maneiras, e entre elas, destacouse a idéia que argilas possuiam hidrogênio que poderia ser facilmente trocado pelo $\mathrm{KCl}$ proveniente da ponte salina, do elec trodo de calomelano. Essa idéia, apesar de ser errônea, serviu de apoio para as curvas de titulação potenciométricas de suspensões de argilas. 
BRADFIELD (1923) foi o primeiro a mostrar, atravês de curvas de titulação potenciomèttrica, que argilas eram colöides ācidos; de comportamento semelhante aos ácidos fracos e como tal, poderiam ser caracterizadas pelas constantes de dissociação. Essa descoberta reforçou a idéia que o, hidrogê nio era o principal cátion responsável pela acidez do solo.

Foi um avanço considerãvel na química de solo, apesar de ter sido também motivo de muita controvérsia, uma vez que, dependenđo da técnica empregada na saturação da argila com hidrogênio e do intervalo de tempo entre o preparo e a titulação potenciométrica, obtinham-se curvas com características tampão diferentes para os mesmos materiais.

PAVER \& MARSHALL (1934) aumentaram as dúvidas existentes sobre a teoria do hidrogênio trocāvel ao mostrarem que argilas isoladas de solos originalmente äcidos possuiam $\mathrm{H}^{+}$ e $\mathrm{Al}^{3+}$ capazes de serem titulados com álcali.

CHERNOV (1947), apös vārios trabalhos sobre a na tureza da acidez dos solos; promulgou a "teoria do alumínio" em seu livro, intitulado "A natureza da acidez do solo", orig代 nalmente publicado em russo e traduzido para o inglês em 1964 . Vários conceitos importantes foram definidos pelo autor:

a) Em solos ácidos o $\mathrm{Al}^{3+}$ é o responsāvel pela acidez trocável, uma vez que, sua energia de adsorção e maior do que a do $\mathrm{H}^{+}$ e $\mathrm{Ca}^{2+}$,

b) A solução de $\mathrm{KCl}$ IN extrai somente $\mathrm{Al}^{3+}$, com exceção de solos orgânicos ou de pH muito baixo, onde existirā também, $\mathrm{H}^{+*}$ trocável nos extratos, 
c) Existe uma reação entre ācidos húmicos com óxidos de alumínio cujos produtos finais são poucos solúveis,

d) $\mathrm{O} \mathrm{Al}^{3+}$ quando titulado com álcali produz substâncias que são adsorvidas pelas partículas coloidais do solo.

Na Inglaterra, SCHOFIELD (1949), mesmo desconhecendo as idéias de CHERNOV (1947), mudou a opinião européia com um estudo sobre os efeitos do $\mathrm{pH}$ no desenvolvimento de car gas elétricas na superfície de argilas de subsolos ácidos de Rothamsted: O autor observou a existência de cargas elétricas positivas em valores baixos de $\mathrm{pH}$, interpretadas como oriundas da protonação nos óxidos de ferro. Por outro lado, em $\mathrm{pH}$ maior que 6,0 havia liberação de cargas elétricas negativas, interpretadas pelo autor, como oriundas da dissociação de radi cais $\mathrm{OH}$ do mineral de argíla. Alèm disso, a lavagem do solo com HCl $0,01 \mathrm{~N}$ libera basés e $\mathrm{Al}^{3+}$ trocâveis. A conclusão final desse trabalho foi que a hidrólise do $\mathrm{Al}^{3+}$ era responsável pelo carāter äcido fraco de suspensões de argila e não a disso ciação de $\mathrm{H}^{+}$como proposto por BRADFIELD (1923).

COLEMAN \& HARWARD (1953) e. HARWARD \& COLEMAN (1954), compararam as curvas de titulação potenciométrica e o calor de neutralização de argilas saturadas com $\mathrm{H}^{+}$, por vārios processos, com argilas saturadas com $\mathrm{Al}^{3+}$ e com resina catiôni ca ("Amberlite" IR 120, ācido forte) também saturada com $\mathrm{H}^{+}$e $\mathrm{Al}^{3+}$. Os autores observaram que argilas $\mathrm{H}^{+}$obtidas por lavagem com $\mathrm{HCl}$ IN ou exaustão de bases com resina trocadora de Ions apre sentavam calor de neutralização de $-13,5 \mathrm{kcal} / \mathrm{mol}$ de 
$\mathrm{NaOH}$ consumido, o que caracteriza a presença de ácido forte. Entretanto, esse valor foi igual para a resina "Amberlite" saturada com $\mathrm{H}^{+}$tendo atribuído portanto, o caráter ácido forte das argilas, ao $\mathrm{H}^{+}$. Por outro lado, a lavagem de argilas com HCl $0,05 \mathrm{~N}$, ou eletrodiálise, produzia um material com característica de ácido fraco, ou seja, calor de neutralização por volta de $-5,4 \mathrm{kcal} / \mathrm{mol}$ de $\mathrm{NaOH}$, valor igual ao da resina "Amberlite" saturada com $\mathrm{Al}^{3+}$. Desses trabalhos, foi concluido que, dependendo da têcnica usada na preparação de argilas, obtinham-se materiais com caracteristicas tampão distintas ${ }^{\text {, sen }}$ do que o carăter ảcido fraco de șuspensões de argila era devi-do ao $\mathrm{Al}^{3+}$, capaz de ser trocado por $\mathrm{KCl}$. IN.

LOW (1955), confirmou as observações de COLEMAN \& HARWARD (1953) utilizando a condutividade elëtrica e potenciometria simultaneamente, durante a titulação de argilas saturadas por misturas de $\mathrm{HCl}$ e $\mathrm{AlCl}_{3}$, em vârias relações. Nesse trabalho, ficou demonstrado que tanto o $\mathrm{Al}^{3+}$ como $\mathrm{H}^{4}$. podem existir em formas trocáveis, contudo, $\mathrm{O} \mathrm{H}^{+}$só existirá em pH menor que 4,0 e portanto, será neutralizado primeiro durante a titulação, o que foi observado pelas inflexões nas curvas de condutividade e potenciometria.

Os trabalhos de CHERNOV et alii (1956), CHERNOV (1959) e COLEMAN \& CRAIG (1961) esclareceram definitivamente as dūvidas ainda existentes sobre a presença do alumĩnio e sua origem, ao mostrarem que argilas saturadas com hidrogênio não eram estäveis e se transformavam espontaneamente em argilas sa turadas com $\mathrm{Al}^{3+}$ e $\mathrm{Mg}^{2+}$, devido ao ataque do hidrogênio à rede 
cristalina dos minerais de argila. Alēm disso, ficou evidenciado que a amplitude dessa transformação dependia do periodo de armazenamento da argila-H, enquanto que a velocidade de transformação exa dependente da temperatura de armazenamento.

Com esses trabalhos, os conceitos sobre a nature za da acidez tornaram-se mais compreensiveis, pois, eles expli cam porque não são observados normalmente teores elevados de hiarogênio trocāvel no solo, e ainda, que o Al ${ }^{3+}$ é conseqüência e não a causa da acidez dos solos.

Não havendo inais dưvidas a respeito da existência do $\mathrm{Al}^{3+}$, as pesquisas voltaram-se mais para a quimica do elemento no solo, formas de ocorrēncia, mẻtodos de extração e seus efejtos no metabolismo de plantas, onde a sua toxicidade foi muito bem documentada, inclusive no Brasil por ARAUUO (1949), que apontava o "aluminio trocāvel" como a possi̊vel cau sa do "crestamento do trigo".

A hidrölise do $A I^{3+}$ foi estudada por SCHOFIELD \& TAYLOR (1954) em soluções diluídas de $\mathrm{AlCl}_{3}$, e foi considera da como a dissociação de um äcido fraco, atravês da seguinte reaçäo:

$$
\left[\mathrm{AI}\left(\mathrm{H}_{2} \mathrm{O}\right)_{6}\right]^{3+}+\mathrm{H}_{2} \mathrm{O}\left[\mathrm{AIOH}\left(\mathrm{H}_{2} \mathrm{O}\right)_{5}\right]^{2+}+\mathrm{H}_{3} \mathrm{O}^{+}
$$

E interessante notax, que os autores apresentaram - $\mathrm{Al}^{3+}$ como Ion hidratado por seis moléculas de àgua. o valor da constante de equilibrio encontrada foi $\mathrm{Ka}=1,05 \times 10^{-5} \mathrm{a}$ $25^{\circ} \mathrm{C}\left(\mathrm{pK}_{1}=4,98\right)$ com um coeficiente de temperatura de $-0,03$ 
unidades $/{ }^{\circ} \mathrm{C}$, sugerindo que 0 mecanismo de reação era muito se melhante ao da dissociação da ãgua.

RAGLAND \& COLEMAN (1960) estudaram a hidrölise do $\mathrm{Al}^{3+}$ em soluções de $\mathrm{AlCl}_{3}$, suspensões de argilas e suspensões de subsolos, com os objetivos de obter a constante de equilíbrio e caracterizar os produtos de hidrölise. Três conclusões importantes foram tiradas desse trabalho:

a) O valor de $\mathrm{pK}$ obtido em solução de $\mathrm{AlCl}_{3}$ foi igual ao proposto por SCHOFIELD \& TAYLOR (1954), nas mesmas condições de equilibrio;

b) A hidrölise do $\mathrm{Al}^{3+}$ é mais intensa ( $\mathrm{pK}$ menor) na presença de solo ou argila do que em soluções de $\mathrm{AlCl}_{3}$, mostrando que os produtos da hidrôlise são adsorvidos no complexo co loidal do solo:

c) O produto final da hidrölise deve ser $A l(O H){ }_{3}^{\circ}$, por duas razões: la.) para cada ion $\mathrm{Al}^{3+}$ hidrolisado são produzidos três Ions $\mathrm{H}^{+}$. 2a.) sua adsorção não altera $\circ$ balanço de cargas elêtricas das argilas. Portanto, a reação proposta foi a seguinte:

$\mathrm{Al}^{3+}+3 \mathrm{H}_{2} \mathrm{O} \rightleftharpoons \mathrm{Al}(\mathrm{OH})_{3}^{\mathrm{O}}+3 \mathrm{H}^{+}$

A evidência de "fixação" de alumînio no espaço interlamelar de minerais de argila do tipo 2:1, foi apresentada por RICH \& OBENSHAIN (1955). Essa "Eixação" de alumínio foi estudada com detalhe por HSU \& RICH (1960), RICH (1960) e JACKSON (1960 e 1963), que a consideraram como a adsorção de hidróxidos ou polímeros de aluminio, resultantes da polimeriza 
ção de produtos intermediārios de sua hidrólise. A caracterís tica mineralógica desses minerais interestratificados, inclusi ve utilizada na sua identificação, ẻ a ausência de colapso nes ses minerais, quando eles são saturados com potássio e posteriormente aquecidos. Consequências importantes ocorrem com es śa adsorção, como a redução da capacidade de troca catiônica, e a presença de uma grande fonte de acidez potencial, uma vez que, os hidróxidos e polîmeros de alumínio são doadores de pró tons ou receptores de hidroxilas.

A adsoxção de hidróxidos de alumínio, polimeriza dos ou não, na superfĩcie ou no espaço interlamelar dos minerais de argila, resulta em formas de alumínio não trocâveis por $\mathrm{KCl} 1 \mathrm{~N}$, contudo è importante ressaltar que a extração com solução normal de acetato de amônio a pH 4,8 pode extrair parte dessas formas, como mostram os trabalhos de SCHWERTMANN \& JACKSON (1964), PRATT \& BAIR (1961), BHUMBLA \& MCLEAN (1965). A formação de complexos entre os hỉdróxidos e polímeros de alu् minio com os grupos funcionais da matéria orgânica do solo, também resultam em formas de aluminnio de difícil extração com KCl IN, e são extraĩdas em maior quantidade pela solução normal de acetato de amônio a pH 4,8, (McLEAN et alii, 1965 e PIONKE \& COREY, 1967).

Na extração de ajuminio no solo com acetato de amônio, normal a pH 4,8 estão envolvidas alēm de reações de troca, reações de solubilização deviđo ao pH da extração. Por essa razão, deve-se referir a essa extração como a quantidade 
de aluminio extraído por acetato de amônio a pH 4,8 e não como aluminio trocável, como às vezes é réferido.

\subsection{Metodos de Recomendação de Calagem.}

\subsubsection{MÉtodos baseados em CuRVAS de titUULAÇÃo POTEN- CIOMÉTRICAS}

Esses métodos geralmente não são empregados em laboratórios de rotina de análise de solo, por serem trabalhosos. Entretanto, são muito importantes por serem considerados padrões e geralmente utilizados para calibrar os métodos rápidos. A incubação de amostras de solos com doses crescentes de carbonato de cálcio durante alguns meses è a metodologia geral mente mais empregada. Após o período de incubação $\circ \mathrm{pH}$ é determinado nas amostras incubadas e obtêm-se curvas de neutrali zação dos solos, das quais a necessidade de calagem pode ser obtida para, qualquer valor de $\mathrm{pH}$ desejado. Um fator importante que deve ser observado, com o uso desse método, é o acủmulo de saịs oriúndos da mineralização da matéria orgânica que ocor re durante o período de incubação e que normalmente deprime os valores de pH. Essa depressão do pH induz a uma recomendação maior de calagem pelos métodos rápidos, como mostram os dados de McLEAN et alii (1966). A titulação potenciométrica de suspensões de solo com soluções de $\mathrm{Ca}(\mathrm{OH})_{2}$ também é bastante utilizada. Essa técnica foi introduzida por VEITCH (1902) e foi aprimorada por BRADFIELD (1942). Nesse caso, o processo è mais rápido que o anterior, mas tem-se que tomar cuidado para 
que $\circ \mathrm{pH}$ desejado alcance $\circ$ ponto de equilíbrio. Para isso , torna-se necessário agitar periodicamente as suspensões e conferir os valores de $\mathrm{pH}$ até que eles atinjam constância em um período mínimo de três dias.

\subsubsection{Métodos baseados no decréscimo do pH de Solu- ÇÕES-TAMPÃO}

Pela primeira vez, BROWN (1943) apresentou um mé todo rápido para determinação da necessidade de calagem, basea do no conceito de decréscimo do pH de uma solução tampão composta de acetato de amônio noṛmal, ajustado, a pH 7,0. A acidez a ser neutralizada era obtida atravês do $\mathrm{pH}$ de equilíbrio de uma suspensão de solo-tampão na relação $1: 10$, senảo conhecí da a curva de titulação potenciométrica do tampão feita com ācido acétịco. Posteriormente WOODRUFF (1948), com base no trabalho de BROWN (1943), propôs uma outra solução tampão, pre parada com acetato de cálcio, p-nitrofenol e óxido de magnésio ajustada a pH 7,0. Para cada 0,1 unidade de decrêscimo do $\mathrm{pH}$ de uma suspensão de solo-ãgua-tampão $(5: 5: 10)$ era necessário 1 meq/lo0g de base para neutralizar a acidez existente e elevar $\circ \mathrm{pH}$ do solo à faixa de 6,0 a 6,5. SHOEMAKER et alii(1961) e MCLEAN et alii (1960) criticaram o método de WOODRUFF (1948) por recomendar pouco calcário para os solos do Estado de OhioUSA.e propuseram uma nova solução, com maior capacidade tampão, composta por p-nitrofenol, trietanoalamina, cromato de po tăssio, acetato de cálcio e cloreto de cálcio, ajustada a a 
pH 7,5, e que acabou ficando conhecida como tampão SMP. Os va lores do pH de equilîbrio de suspensões de solo-ãgua-tampão na relação 5:5:10, de vārias amostras de solos, foram correlacionadas com a necessidade de calagem para elevar o pH do solo ao valor 6,8, obtịda pelo método da incubação $\operatorname{com} \mathrm{CaCO}_{3} \cdot$ Desse modo, os autores obtiveram uma curva de calibração do método . que posteriormente pôde ser convertida em tabela para a recomendação de calagem.

O método SMP é utilizado nos Estados do Rio Gran de do Sul e Santa Catarina com algumas modificações (BOHNEN et alii 1971), principalmente no valor do pH desejado, com valores em torno de 6,0 e na relação solo-ăgua-tampão de $6: 6: 6$, ou seja, a quantidade de tampão utịlizada è quase a metade da usa da no método original. Essa modificação aumenta a sensibilidade do método e é indisperisāvel para a sua ađaptação em solos com menor capacidade tampão.

o mëtodo SMP também foi adaptado e testado por FREITAS et alii (1968) para os solos do Estado de são Paulo e CATANI \& ALONSO (1969) para os solos do município de Piracicaba. CATANI \& ALONSO (1969) mantiveram a mesma relação entre solo-āgua-tampão do método SMP, enquanto que FREITAS et alii (1968) dobraram a quantidade de tampão em relação a usada no método SMP original, utilizando a relação 6:5:20, o que provocou perda de sensibilidade do método, fazendo com que a necessidade minima de calagem recomendada fosse 3,2 t/ha, RAIJ et alii (1979) estudaram algumas relações entre solo-ăgua-tampão para adaptar o método SMP para os solos do Estado de são Paulo. 
Os autores observaram que a relação 10:20:10 tornava o mëtodo muito sensivel para os solos deste éstado e apresentaram tabela para calagem em três níveis, tendo como meta atingir os valores de pH de 5,$5 ; 6,0$ e 6,5 .

Recentemente, YUAN $(1974,1976)$ introduziu uma nova idêia de recomendação de calagem com base em soluções-tam pão, com o conceito do duplo tampão, visando aumentar a sensibilidade desses métodos em solos de baixa capacidade de troca de câtions. Esse método utiliza uma mistura de tampões compos ta por tris (hidroximetil-aminoetano), imidazol, cromato de po tássio, pirimidina e cloreto de cålcio. São preparadas duas soluções de mesma composição, pore̊m uma ajustada a pH 7,0 e a outra a pH 6,0. Essas soluções são preparadas de tal modo que tenham uma redução linear de 0,1 unidade de $\mathrm{pH}$ para ... cada 0:1 meq de âcido forte adicionado em $50 \mathrm{ml}$ dessas sol.uções. Por essa têcnica a necessidade de calagem é diretamente proporcional à capacidade tampão do solo $(\theta)$ definida pela seguinte fóx mula: $d=\left(d_{1}-d_{2}\right) /\left(h_{1}-h_{2}\right)$; onde $d_{1}$ e $d_{2}$ são os valores da acidez verificados pelo decrêscimo de $\mathrm{pH}$ das soluções tampões ajustadas em $\mathrm{pH} 7,0$ e 6,0 respectivamente, e $\mathrm{h}_{1}$ e $\mathrm{h}_{2}$ são os valores do $\mathrm{pH}$ de equilíbrio das duas soluções em contato com a amostra de solo. A förmula para o călculo da necessi dade de calagem (NC) fica assim representada: $N C=d_{1}+d\left(h-h_{1}\right)$ x 22,4; onde h̀ é o valor de $\mathrm{pH}$ desejado e 22,4 é um fator de conversão para $t /$ ha de $\mathrm{CaCO}_{3}$.

MCLEAN et alil (1978) testaram o conceito do du- 
plo tampão, utilizando, porēm, a mesma solução do mētodo SMP original. Os autores concluiram que com essa técnica a sensibilidade do método SMP aumentava, principalmente em solos com baixa capacidade tampão. Por outro lado, o mëtodo tornou-se bem mais trabalhoso que o método original.

\subsubsection{MËtodo baseado no teor de alumínio trocâvel}

O trabalho clāssico de DAIKUHARA (1914) que preconizou a determinação de $\mathrm{Al}^{++t}$ por meio de extração com $\mathrm{KCl}$ iN e posterior títulaçäo com $\mathrm{NaOH}$, serviu de base para o desenvol vimento desse método. Atravēs de VAGELER $(1932,1956)$ o princípio do mętodo jå era conhecido no Brasil, porēm, foi pela di vulgação internacional, depois dos trabalhós de COLEMAN et alii (1958) e KAMPRATH (1970), que preconizaram a idëia de que a calagen deve ser suficiente para neutralizar o alumínio trocăvel, è que o mêtrodo teve maior aceitação no país. Esse critẻrio está ligado ao conceito de CTC efetiva, e ainda, que abaixo de $\mathrm{pH} 5,4$ a capacidade tampão do solo é devida exclusivamente ao $\mathrm{Al}^{+++}$. A difusão desse mêtodo no País, realmente aconteceu com o.Programa Internacional de Anălise do Solo(CATE 1965), ueilizando-se a fórmula Al x 1,5 = t/ha de $\mathrm{CaCO}_{3}$ para 0 cálculo de calagem. Contudo, devido às pequenas dosagens noxmalmente recomendadas, foi Introduzido um outro cričēio complementar, que procurava garantir os teores de cálcio mais mag nésio no solo ao valor de $2 \mathrm{meq} / 100 \mathrm{~cm}^{3}$ de terra, caso o solo possua menos de $2 \%$ de matéria orgânica, e ao valor 3 quando o 
solo possui mais de $2 \%$ de matéria orgânica. No Estado de são Paulo a recomendação de calagem é feita geṛalmente pela alternativa que recomenda a maior dose, jă no Estado de Minas Gerais a recomendação é feita somando-se as duas alternativas, utilizando-se a fôrmula (Al $\times 2,0)+2-(\mathrm{Ca}+\mathrm{Mg})=t / h a d e$ $\mathrm{CaCO}_{3}$ para o călculo de calagem (EPAMIG, 1978).

Como se pode observar, esse método è aproximado pois não considera a capacidade tampão do solo acima da fai xá de pll 5,4 a 5,6. A'lém disso, estão sendo utilizadas adap tações empiricas juntamente com o conceito original, geralmente na tentativa de se recomendar mais calcário.

\subsubsection{MËtodos baseados na correlaç̃̃̃o entre 0 . PH E SATURAÇÃO DE BASES}

Esses mëtodos, alēm da determinação da soma cẹ bases (câlciò, magnêsio, potássio e, alquns casos, sôdjo), geralmente feita nos laboratórios de rotina de análise de solo, requerem tambêm a determinação de $\mathrm{H}+\mathrm{Al}$ e ainda a CTC do solo para o câlculo da calagem. Tanto a determinação de $\mathrm{H}+\mathrm{Al}$ como a CTC envolvem a extração com uma solução de sal tamponado, ou uma solução composta de sais neutros misturados com outros tampões. Essas soluções são sempre ajustadas a um determinado $\mathrm{pH}$, que corresponde ao valor do $\mathrm{pH}$ de referência para a medida da CTC. JONES (1913) foi o pioneiro em determinar $\mathrm{H}+\mathrm{Al}$ no solo através da extração com acetato de cálcio. o método consistia em adicionar alguns miligramas do sal a uma determinada 
quantidade de solo, com posterior adição de água. A suspensão era agitada durante algumas horas e após a filtragem procediase a titulação do filtrado $\mathrm{com} \mathrm{Ca}(\mathrm{OH})_{2}$ usando-se a fenolftaleí na como indicador. Esse método foi aprimorado e modificado por PARKER (1929) que substituiu o acetato de cálcio por solução normal de acetato de bário a $\mathrm{pH} 7,0$ e os valores de $\mathrm{H}+\mathrm{Al}$ eram obtidos através da titulação potenciométrica com $\mathrm{Ca}(\mathrm{OH})_{2}$ atẻ o ponto de neutralidade.

No Brasil, esse método foi introduzido primeiramente por VAGELER (193\%), em adaptação, na qual $\mathrm{log}$ de solo eram percolados por duas vezes consecutivas com volumes de l00ml de uma solução de acetato de cálcio, normal a pH 7,0. Com essas duas extrações consecutivas, aplicava-se o princípio de um nủmero infinito de extrações mediante a resolução da ęquação hiperbölica de VAGELER (1932) para o cálculo dos valores de $\mathrm{H}+\mathrm{Al}$, conforme a descrição detalhada de PAIVA NETO et alii (1947). VETTORI (1948), com base nos trabalhos de PARKER (1929) e VAGELER (1932) prọôs uma outra adaptação no Bxasil. Atualmente ela consiste em pesar $10 \mathrm{~g}$ de solo e adicionar $150 \mathrm{ml}$ de solução normal de acetato de cálcio a pH 7,0. Aos teores de $\mathrm{H}+\mathrm{Al}$ determinados por titulação $\mathrm{com} \mathrm{NaOH}$ são adicionados mais $10 \%$, pois o autor considera que a extração corresponde a apenas 90\% do valor real (VETTORI, 1969).

Por outro lado, os conceitos de CTC do solo deri nida como sendo soma de $\mathbf{S}+(H+A l)$, bem como, $O$ concelto de saturação de bases definida pelo quociente $S$ × 100/CTC de- 
vem-se a HISSINK (1924). Esses conceitos foram usados no trabalho de MERKLE (1934) e posteriormente muito divulgados com os trabalhos de MEHLICH $(1942,1943)$, que calculou a saturação de bases mediante determinação da CTC com extração de $H+A I$ com uma solução de $\mathrm{BaCl}_{2} 0,5 \mathrm{~N}$ e trietanoalamina $0,055 \mathrm{~N}$ a pH 8,2 . Esse valor de $\mathrm{pH}$, corresponde ao $\mathrm{pH}$ máximo do solo em equilíbrio com um excesso de $\mathrm{CaCO}_{3}$, à pressão parcial de $\mathrm{CO}_{2}$ do so 1o. O autor justificou esse valor da CTC devido à ocorrência nos Estados Unidos de solos calcários que possuem pH maior que 7.0. Esse método, apesar de não justificar o seu uso no Brasil, tem sido atê hoje empregado e ê motivo de controvêrsia en tre os químicos e especialistas em fextilidade do solo.

A divulgação do critẻrio de recomendação de cala gem com base na correlação entre 0 pH e a saturação de bases no Brasil, ocorieu realmente com o trabalho de CATANI \& GALLO (1955). A fórmula deduzida para o cálculo da calagem é dada a seguir:

$$
\mathrm{NC}=\mathrm{H} \frac{\left(i_{2}-i_{1}\right)}{\left(1-i_{1}\right)}=t / h a \text { de } \mathrm{CaCO}_{3}
$$

onde:

$\mathrm{H}=$ Teor de $\mathrm{H}+\mathrm{Al}$, em meq $/ 100 \mathrm{~g}$ de terra, determinado pela extração com acetato de cälcio a pH 7,0.

$i_{2}=$ Saturação de bases desejada $(70 \%)$.

$i_{1}=$ Saturação de bases atual do solo, obtida atravës do pH empregando-se a equação: $\mathrm{pH}=4,288+0,031.26 \mathrm{~V}$ \% $(x=0,97)$. 
Esse método dispõe de fundamentos teóricos, é re lativamente preciso, entretanto, não é muito ajustado às condi ções de laboratôrio de rotina que realizam grande número de anālises diariamente, devido a determinação de $\mathrm{H}+\mathrm{Al}$ pelo método do acetato de câlcio ser um tanto trabalhosa.

RAIJ et alii (1979) observaram estreita correlação entre os valores de $\mathrm{H}+\mathrm{Al}$ obtidos pelo mëtodo do acetato de cálcio (CATANI \& GALLO, 1955) com os valores do $\mathrm{pH}$ da suspensão solo-ågua-tampão SMP (10:20:10), mostrando a possibilidade de se determinas $\mathrm{H}+\mathrm{Al}$ por meio de leituras potenciométricas do $\mathrm{pH}$ de equilîbrio do ṫampão SMP do solo, utilizando--se a seguinte equação de regressão: $\mathrm{y}=2,8-4,18 \times(\mathrm{r}=-0,975)$. Essa equação foi calculada com os dados de uma população de sô los, na qual não se dispunha de solos com CTC bastante elevada e portanto não permite o cälculo de $\mathrm{H}+\mathrm{Al}$ em valores acima de $8 \mathrm{meq} / 100 \mathrm{~cm}^{3}$ de terra: 


\section{MATERIAL E MÉTODOS}

\subsection{Solos}

\subsubsection{DESCRI GÃO DOS SOLOS ESTUDADOS}

Os solos utilizados nesse estudo encontram-se listados na tabela 1 , juntamente com os locais onde foram cole tados. Eles representam geográfica e economicamente as princi. pais unidades de mapeamento do Estado de São Paulo. As amostras foram coletadas na camada arāvel, dando-se preferência a locais próximos aos perfis descritos pela equipe de Pedologia do Instituto Agronômico, uma vez que, nesses perfis dispõem-se da descrição morfolōgica e a mineralogia, tanto das frações grosseiras como também da fração argila. Algumas amostras foram coletadas dentro de unidades de mapeamento da carta de solos. do Estado de são Paulo, procurando-se locais em que a descrição morfológica assemelha-se com as respectivas unidades ta xonômicas descritas nos relatőrios da Comissão de solos (BRA- 


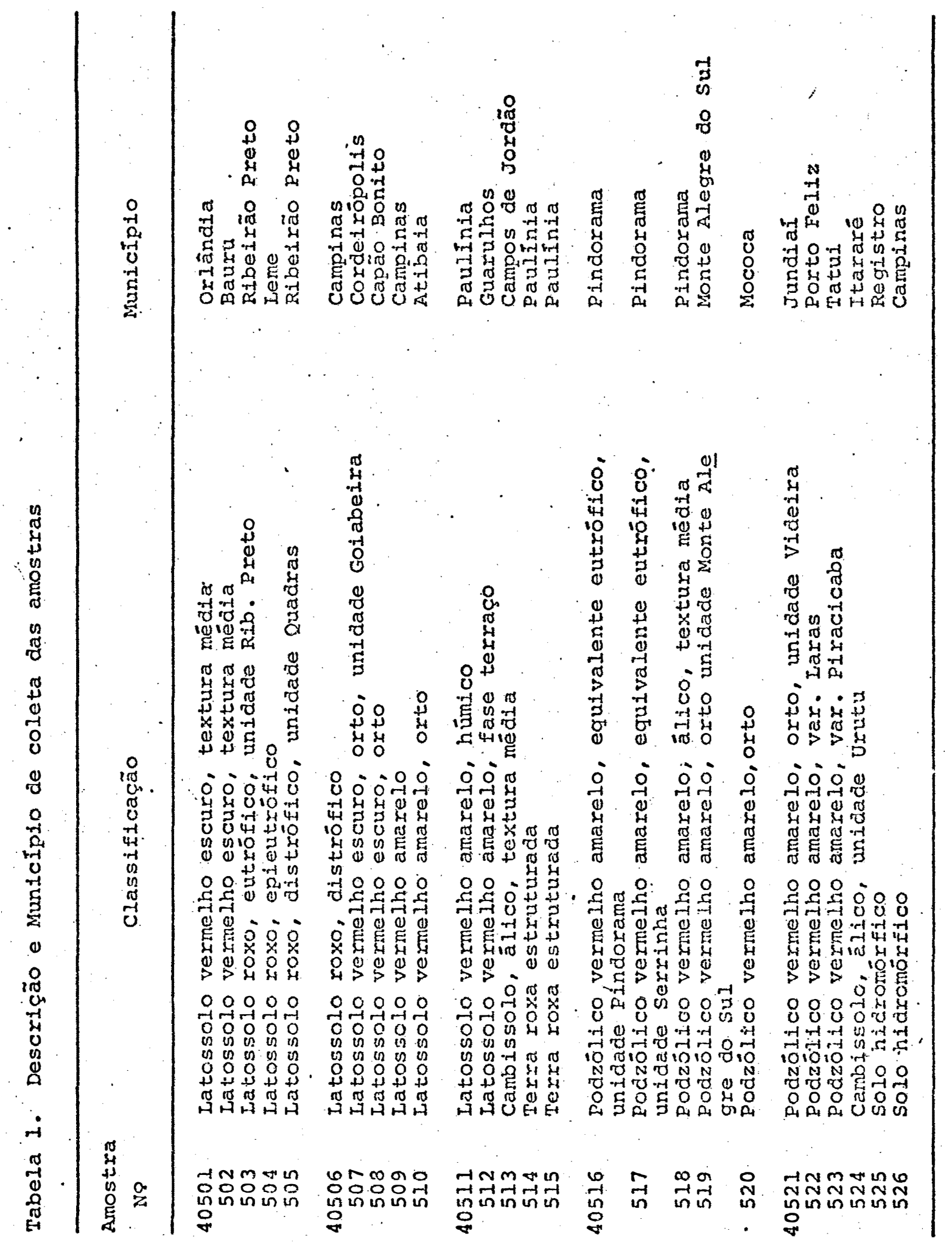


SII, 1960)

Os critērios adotados na seleção dessas amostras foram primeiramente a representatividade dos solos do estado, ampla variação nos teores de argila e matêria orgânica e nos teores de aluminio trocấvel e bases trocāveis, com objetivo de obter-se uma população de solos com amp̉la variação na capacidą de tampão.

Uma segunda população de solos foi selecionada inteiramente ao acaso, om amostras que foram enviadas por lavradores à Seção de Fertilidade do Solo para anâlise de rotina. Elas totalizam 130 amostras que foram usadas para traçar uma equação de regressão entre.o pH e saturação de bases, con o in teresse de se aferir a representatividade da população anterior, em relação aos solos do Estado de são Paulo.

\subsubsection{Preparo das amostras de terra}

Apōs à coleta, as amostras de terra foram primeí ramente secas ao ar, devido ao grande volume coletado. Apōs a secagem ao ar, foi retirada uma nova amostra de aproximadamente $500 \mathrm{~g}$ que foi seca em estufa a $60^{\circ} \mathrm{C}$ e posteriormente moída e peneirada em mallua de $2 \mathrm{~mm}$ de abertura. Estando preparadas, as amostras foram protocoladas e encaminhadas para as determinações de laboratörìo. 


\subsection{DETERMINAÇ̃̃ES, DE LABORATÓRIO}

Com exceção do teor de argila, as demais determinações de laboratōrio foram feitas sempre com quatro repetições em dias diferentes, sendo que, em algumas determinações, como é o caso do $\mathrm{pH} \mathrm{e}^{+}+\mathrm{Al}^{3+}$ foram utilizadas inclusive laboratoristas diferentes, com o objetivo de se avaliar melhor a reprodutividade dos métodos empregados.

E importante salientar ainda, que com exceção da determinação de argila que foi feita com base no peso de terra, as demais determinações foram feitas sempre com base no vo lume de terra.

\subsubsection{Matéria orgânica}

o teor de matéria orgânica no solo foi determina do indiretamente através da anălise do teor de carbono orgânico, utilizando-se o fator 1,72 para posterior conversão para matéria orgânica. A oxidação do carbono orgânico foi feita por via úmida utilizando-se uma solução de bicromato de sódio na presença de ācido sulfürico para a oxidação e posterior determinação em colorímetro, seguindo-se o mētodo descrito por QUAGGIO \& RAIJ (1979).

3.2.2 PH EM ÁGUA E EM SOLUÇÃO de CACL $\quad 0,01 M$

A determinação do $\mathrm{pH}$, tanto em água como em solu 
ção de $\mathrm{CaCl}_{2}$ 0,0iM foi feita na relação $1: 2,5$, de acordo com a padronização feita pela Sociedade Internacional de Ciência do Solo. $\mathrm{Em} 10 \mathrm{~cm}^{3}$ de terra foram adicionados $25 \mathrm{ml}$ de água ou de solução de $\mathrm{CaCl}_{2}$ 0,01M, agitando-se durante quinze minutos e deixando a suspensão em repouso durante 30 minutos. As leituras foram feitas em potenciōmetro marca Metrohm -E 500, munido de eléctrodo, combinado, devidamente calibrado. Tomou-se sempre o cuidado de que as leituras potenciométricas fossem feitas na mesma profundidade de tal modo que o eléctrodo apenas encostasse na fase sedimentada, mantendo-se assim, a ponte salina em contato com o sobrenadante.

\subsubsection{PH DE EQUILİBRIO DA SOLUÇÃO TAMPÃO COM O SOLO 3.2 .3 .1 COMPOSIÇÃO E PREPARO DA SOLUÇÃO TAMPÃO}

A solução tampão utilizada nesse estudo foi introduzida originalmente por SHOEMAKER et alii (1961) e tornouse conhecida como solução tampão SMP. Ela foi empregada no presente trabalho com concentração dobrada em relação a solução original, com a seguinte composição por litro de solução:

- Paranitrofenol

- Trietanoalamina

- Cromato de potássio $\left(\mathrm{K}_{2} \mathrm{Cr}_{2} \mathrm{O}_{4}\right)$

- Acetato de cálcio $\mathrm{Ca}\left(\mathrm{CO}_{2} \mathrm{CH}_{3}\right)_{2}$

- cloreto de cálcio $\left(\mathrm{CaCl}_{2} \cdot 2 \mathrm{H}_{2} \mathrm{O}\right)$

- $\mathrm{pH}$ ajustado em 7,5 com $\mathrm{NaOH}$
$3,6 \mathrm{~g}$

$5,0 \mathrm{ml}$

$6,0 \mathrm{~g}$

$4,0 \mathrm{~g}$

$106,2 \mathrm{~g}$ 
Alguns cuidados devem ser tomados no preparo des sa solução, como é o caso de dissolver o p-nitrofenol separada mente em aproximadamente $200 \mathrm{ml}$ de água quente, e juntá-lo aos demais reagentes no balão por meio de filtragem, no caso de se observar impurezas na solução, após a dissolução.

o pH dessa solução tampão deve ser ajustado apōs algum tempo do preparo da mesma, dando-se a preferência para o preparo à tarde e ajuste do pH na manhã seguinte. Além disso, é aconselhável guardá-la em refrigerador.

\subsubsection{Procedimento}

$\mathrm{Em} 10 \mathrm{~cm}^{3}$ de terra foram adicionados $25 \mathrm{ml}$ de água ou solução de $\mathrm{CaCl}_{2}$ 0,01M e obtiveram-se desse modo, os valores de $\mathrm{pH}$ em água ou em $\mathrm{CaCl}_{2} 0,01 \mathrm{M}$ respectivamente, conforme já foi descrito no ítem 3.2.2. Após a determinação do pH, adị cionaram-se $5 \mathrm{ml}$ de solução tampão e agitou-se durante 15 minutos. Um período de repouso de 60 minutos foi necessário para que o equilíbrio entre o tampão com o solo fosse atingido. Após o período de repouso, as leituras potenciométricas foram feitas nas mesmas condições já descritas anteriormente no ítem 3.2.2. Foi observado tambëm a importância de uma boa lavagem do eléctrodo com um jato de água, entre as leituras, para evitar-se que o eléctrodo ficasse com "memória" da leitura anterior.

A determinação do $\mathrm{pH}$ do tampão em equilíbrio com o solo foi feita sempre na relação 10:25:5 entre solo-água e 
solução tampão respectivamente, mantendo-se desse modo, as mes mas proporçōes empregadas no trabalho de RAIJ et alii (1979), que era de 10:20:10, porém a solução tampão possuia a metade da concentração empregada nesse estudo. Essa modificação foi introduzida para que fosse possivel determinar tanto $0 \mathrm{pH} e m$ água como $\circ$ em $\mathrm{CaCl}_{2}$ na relação 1:2,5, mantendo-se a padronizą ção proposta pela Sociedade Internacional de Ciência do Solo.

\subsubsection{CÁTIONS TROCĀVEIS}

O cálcio, magnésio e aluminio foram extraídos com solução de $\mathrm{KCl}$ 1N, na relação' $1: 10$. Do extrato de $\mathrm{KCl} \cdot 1 \mathrm{~N}$, foi retirada uma alíquota de $0,5 \mathrm{ml}$ e a ela foram adicionados 10ml de solução de óxido de lantânio à $0,1 \%$. para posterior de terminação do cálcio e magnésio em espectrofotômetro de absorção atômica marca Perkin-elmer, modelo 303. Uma outra alíquota foi extraída para determinação do alumínio trocável, median te titulação desse extrato com $\mathrm{NaOH} 0,01 \mathrm{~N}$, utilizando-se azul de bromotimol como indicador.

A determinação do potássio trocável foi feita me diante extração $\mathrm{com} \mathrm{H}_{2} \mathrm{SO}_{4} 0,05 \mathrm{~N}$, na relação $1: 10$ e posterior determinação utilizando-se fotômetro de chama marca Corning, modelo 400 , devidamente calibrado.

As marchas analiticas utilizadas para a determinação dos cations trocáveis, estão descritas com detalhes no trabalho de RAIJ \& ZULLO (1977). 


\subsubsection{H + Al pelo método da extração com acetato de CÄLCIO}

A extração foi feita com solução normal de aceta to de cálcio a $\mathrm{pH} 7,0$, na qual $5,0 \mathrm{~cm}^{3}$ de terra foram agitados durante 30 minutos com 100ml de solução extratora. Após o perỉodo de agitação procedeu-se a filtragem recebendo-se o filtrado em balão volumétrico de $100 \mathrm{ml}$. Do extrato de solo assim obtido, retirou-se uma alíquota de $25 \mathrm{ml}$ a qual foi titulada com solução de $\mathrm{NaOH} 0,025 \mathrm{~N}$ usando-se três gotas de solução alcoólica de fenolftaleína a 1:\% como indicador. O número de mililitros de $\mathrm{NaOH} 0,025 \mathrm{~N}$ gastós na titulação vezes dois corresponde ao número de miliequivalente de $(H+A l) / 100 \mathrm{~cm}^{3}$ de terra. Esse método foi descrita por CATANI \& GALLO (1955).

\subsubsection{TEOR DE ARGILA}

A determinação da argila foi feita pelo mëtodo da pipeta, utilizando-se soda e hexametafosfato como dispersan tes. O procedimento analítico seguido, estä descrito com detalhes no trabalho de RAIJ \& ZULLO, (1977).

\subsection{CÄLCULO DA SOMA DE BASES, CAPACIDADE DE TROCA DE CÁ- TIONS. E SATURAÇÃOO DE BASES NO SOLO}

A soma de bases (S) foi considerada nesse trabalho como sendo a soma dos teores trocáveis de $\mathrm{Ca}^{2+}, \mathrm{Mg}^{2+}$ e $\mathrm{K}^{+}$ 
não considerando-se os teores de $\mathrm{Na}^{+}$, uma vez que, nos solos estudados os teores de sódio trocável são bem menores do que os teores de potássio e portanto podem ser desprezados.

o valor T do solo foi sempre obtido pelo processo indireto, ou seja, acrescentando-se à soma de bases (S) os valores de $\mathrm{H}+\mathrm{Al}$, tendo portanto, $\mathrm{O} \mathrm{pH} 7,0$ como $\mathrm{O} p H$ de referência.

A saturação de bases do solo (Vঃ) foi calculada pelo quociente entre a soma de bases (S) e a CTC do solo, multiplicado por 100 para expressão dos resultados em porcentagem $(V 8=S \times 100 / T)$.

Calculou-se, também, a CTC efetiva do solo, defi nida como a capacidade de retenção de cátions ao $\mathrm{pH}$ original do solo, acrescentando-se à soma de bases os valores de $\mathrm{Al}^{3+}$. Com base nessa estimativa de $T$, foram obtidos os valores da saturação de aluminio (Al o) através do quociente entre o teor de $\mathrm{AI}^{3+}$ e a CTC efetiva do solo multiplicado por 100 para expressão dos resultados em porcentagem $A l g=A I^{3+} \times 100 /\left(S+A I^{3+}\right)$.

\subsection{ANALISES ESTATISTICAS}

As anālises estatísticas foram baseadas principalmente em anālise de regressão, cujas equações e respectivos coeficientes de correlação foram calculados com o auxílio de uma calculadora marca Hewellet-Packard modelo 9820 , com plotador, utilizando-se os programas da seção de climatologia do Instituto Agronômico. 
Em algumas equações de regressão, foram calculados os intervalos de confiança para a estimativa de y dessas equações, utilizando-se o seguinte modelo matemático descrito POY SNEDECOR \& COCHRAN (1976):

$$
\hat{y}=y \pm t . s \sqrt{\frac{1}{N}+\frac{(x i-\bar{x})^{2}}{(x i-\bar{x})^{2}}}
$$

onde:

$$
\begin{aligned}
\hat{y}= & \text { intervalo de confiança para estimativa de } y \\
y= & \text { valor de } y \text { obtido através da equação de regressão } \\
t= & \text { valor de } t \text { para o nível de } 5 \% \text { de probabilidade } \\
\mathbf{s}= & \text { desvio padrão, obtido através da anālise de variância } \\
& \text { das equações de regressão } \\
N= & \text { número de pontos utilizados no cálculo da equação de } \\
& \text { regressão } \\
\bar{X}= & \text { valox de } x \text { médio } \\
(X i ~ & -\bar{x})^{2}=\text { Soma de quadrado de } x
\end{aligned}
$$




\section{RESULTADOS E DISCUSSÃO}

\subsection{Características gerais dos SOlos}

Os resultados de anālises químicas e os teores de argila dos solos estudados encontram-se na Tabela 2. Obser va-se que, com exceção de alguns solos eutróficos incluídos neste estudo, os demais solos são pobres em bases trocáveis, e alguns apresentam teores extremamente baixos de cálcio e magnê. sio. Por outro lado, os teores de aluminio trocável, com algu mas exceções, são geralmente baixos, e normalmente muito menores do que os teores de hidrogênio. Para as amostras estudadas, encontrou-se um teor médio de $0,83 \mathrm{meq}$ de $\mathrm{Al}^{3+} / 100 \mathrm{~cm}^{3}$ de terra, o que de certo modo, concorda com os resultados obtidos em um levantamento (l) realizado pela Seção de Fertilidade do Solo do Instituto Agronômico, em amostras de agricultores pau-

(1) Levantamento realizado por amostragem de $1 \%$ no total de 14400 amostras de lavradores, cujos resultados não foram publicados. 
Tabela 2. Resultados analíticos das amostras dos solos estudados

\begin{tabular}{|c|c|c|c|c|c|c|c|}
\hline \multirow{2}{*}{$\begin{array}{c}\text { Amostra } \\
\text { No }\end{array}$} & \multirow{2}{*}{ M.O. } & \multirow{2}{*}{$\begin{array}{l}\text { Teor de } \\
\text { argila }\end{array}$} & \multicolumn{4}{|c|}{ Cations trocáveis } & \multirow{2}{*}{$\begin{array}{c}\text { Soma de } \\
\text { bases }\end{array}$} \\
\hline & & & $\mathrm{Al}^{3+}$ & $\mathrm{Ca}^{2+}$ & $\mathrm{Mg}^{2+}$ & $\mathrm{K}^{+}$ & \\
\hline & $---\infty \frac{9}{8}$ & $-\infty---\infty$ & \multicolumn{5}{|c|}{$-\infty-\infty-m$ meq $/ 100 \mathrm{~cm}^{3}$ de solo- } \\
\hline $\begin{array}{r}40501 \\
502 \\
503 \\
504 \\
505\end{array}$ & $\begin{array}{l}2,10 \\
1,10 \\
6,50 \\
5,70 \\
3,40\end{array}$ & $\begin{array}{l}29,0 \\
15,0 \\
65,0 \\
57,0 \\
72,0\end{array}$ & $\begin{array}{l}0,00 \\
0,10 \\
0,10 \\
0,00 \\
0,30\end{array}$ & $\begin{array}{r}1,87 \\
0,67 \\
5,65 \\
10,12 \\
1,35\end{array}$ & $\begin{array}{l}1,08 \\
0,31 \\
2,38 \\
2,72 \\
0,91\end{array}$ & $\begin{array}{l}0,13 \\
0,07 \\
0,19 \\
0,66 \\
0,11\end{array}$ & $\begin{array}{r}3,08 \\
1,05 \\
8,22 \\
13,50 \\
2,37\end{array}$ \\
\hline $\begin{array}{r}40506 \\
507 \\
508 \\
509 \\
510\end{array}$ & $\begin{array}{r}2,50 \\
4,30 \\
11,30 \\
1,90 \\
7,20\end{array}$ & $\begin{array}{l}40,0 \\
61,0 \\
46,0 \\
39,0 \\
45,0\end{array}$ & $\begin{array}{l}0,40 \\
2,30 \\
0,00 \\
1,20 \\
2,00\end{array}$ & $\begin{array}{l}0,77 \\
0,22 \\
8,40 \\
0,15 \\
0,37\end{array}$ & $\begin{array}{l}0,35 \\
0,13 \\
3,19 \\
0,20 \\
0,16\end{array}$ & $\begin{array}{l}0,12 \\
0,16 \\
0,66 \\
0,10 \\
0,15\end{array}$ & $\begin{array}{r}1,24 \\
0,51 \\
12,25 \\
0,45 \\
0,68\end{array}$ \\
\hline $\begin{array}{r}40511 \\
512 \\
513 \\
514 \\
515\end{array}$ & $\begin{array}{r}4,30 \\
4,20 \\
30,00 \\
1,50 \\
1,60\end{array}$ & $\begin{array}{l}49,0 \\
76,0 \\
19,0 \\
60,0 \\
34,0\end{array}$ & $\begin{array}{l}1,20 \\
2,20 \\
4,30 \\
0,10 \\
0,00\end{array}$ & $\begin{array}{l}0,95 \\
0,27 \\
0,25 \\
3,15 \\
2,90\end{array}$ & $\begin{array}{l}0,35 \\
0,09 \\
0,14 \\
0,85 \\
0,50\end{array}$ & $\begin{array}{l}0,14 \\
0,11 \\
0,21 \\
0,35 \\
0,17\end{array}$ & $\begin{array}{l}1,44 \\
0,47 \\
0,60 \\
4,35 \\
3,57\end{array}$ \\
\hline $\begin{array}{r}40516 \\
517 \\
518 \\
519 \\
520\end{array}$ & $\begin{array}{l}1,90 \\
2,10 \\
1,30 \\
3,50 \\
3,70\end{array}$ & $\begin{array}{l}15,0 \\
15,0 \\
21,0 \\
46,0 \\
36,0\end{array}$ & $\begin{array}{l}0,00 \\
0,00 \\
0,70 \\
0,50 \\
0,10\end{array}$ & $\begin{array}{l}2,37 \\
3,45 \\
0,60 \\
1,27 \\
2,32\end{array}$ & $\begin{array}{l}0,41 \\
0,65 \\
0,15 \\
0,94 \\
1,49\end{array}$ & $\begin{array}{l}0,23 \\
0,29 \\
0,12 \\
0,37 \\
0,37\end{array}$ & $\begin{array}{l}3,01 \\
4,39 \\
0,87 \\
2,58 \\
4,18\end{array}$ \\
\hline $\begin{array}{r}40521 \\
522 \\
523 \\
524 \\
525 \\
526\end{array}$ & $\begin{array}{r}3,20 \\
1,90 \\
2,00 \\
5,90 \\
25,00 \\
11,11 .\end{array}$ & $\begin{array}{l}26,0 \\
16,0 \\
34,0 \\
28,0 \\
45,0 \\
39,0\end{array}$ & $\begin{array}{l}0,20 \\
0,10 \\
1,00 \\
1,80 \\
0,70 \\
2,50\end{array}$ & $\begin{array}{l}2,27 \\
1,65 \\
0,55 \\
0,42 \\
4,57 \\
2,25\end{array}$ & $\begin{array}{l}1,04 \\
0,45 \\
0,14 \\
0,17 \\
1,75 \\
0,60\end{array}$ & $\begin{array}{l}0,31 \\
0,27 \\
0,09 \\
0,16 \\
0,41 \\
0,34\end{array}$ & $\begin{array}{l}3,62 \\
2,37 \\
0,78 \\
0,75 \\
6,73 \\
3,19\end{array}$ \\
\hline
\end{tabular}


listas analisadas em 1981. Nesse levantamento, observou-se que $75 \%$ do total de amostras possuiam menos que 0,5 meq de $\mathrm{Al}^{3} /$ $100 \mathrm{~cm}^{3}$ e $90 \%$ delas possuiam menos que 1,0 meq de $\mathrm{Al}^{3+} / 100 \mathrm{~cm}^{3}$ de terrạ.

\subsubsection{CAPACidade tAMPÃo dAS aMOSTRAS Estudadas}

A capacidade tampão do solo depende da natureza de seu complexo coloidal, e pode ser definida como a sua resís tência a mudanças de pH, devido a adição de quantidades de ácị do ou de base. Ela pode ser determinada através da curva de titulação potenciométrica do solo, e poderá se expressa pela relação $\mathrm{pH} / \Delta \mathrm{H}^{+}, \mathrm{pH} / \Delta \mathrm{OH}^{-}$ou em unidades de $\mathrm{pH} /$ meq de $\mathrm{H}^{+}$ou $\mathrm{OH}^{-}$adicionadas a uma determinada quantidade de terra. Por ou tro lado, capacidaḍe tampão do solo é diretamente proporcional a sua CTC, e no caso de recomendação de calagem, ela poderä ser considerada, caso sejam conhecidos os valores de $\mathrm{T}$ e acidez potencial dos solos.

Nesse estudo, procurou-se inferir a capacidade tampão dos solos através dos valores de $T$ e medir a contribuição das frações orgânica e mineral para a CTC desses solos. Obteve-se estreita correlação ( $r=0,94 * *)$ entre os valores de T e teores de matéria orgânica dos solos, a qual, está representada na Figura 1. O mesmo não foi observado entre os valores de CTC e teores de argila $(r=0,22)$, e com 0 uso de regressão múltipla observou-se que a introdução do teor de argila contribuiu para a redução do coeficiente de correlação 


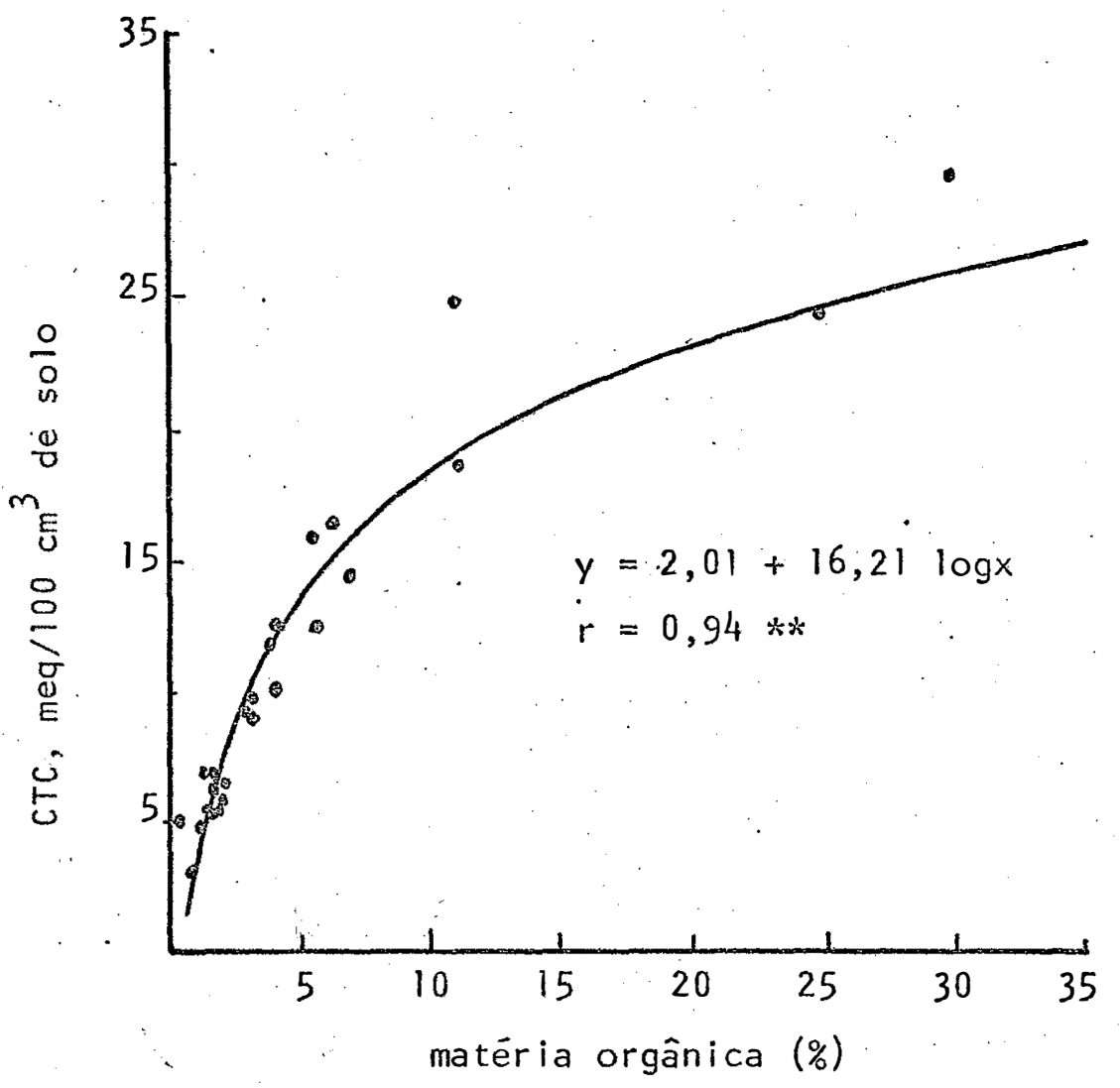

Figura 1. Correlação entre os teores de matēria orgânica do solo e CTC determinada pe lo método da extração com acetato de cälcio. 
$(R=0,87)$

Esses resultados mostram que para as camadas superficiais dos solos do Estado de são Paulo, a capacidade de troca de cátions é dependente principalmente da fração orgânica, enquanto que a contribuição da fração mineral é modesta. Eles estão coerentes com os resultados obtidos anteriormente para os solos do mesmo Estado, por VERDADE (1956) que usando a técnica de se determinar a CTC na amostra intacta e após a destruição da matéria orgânica pelo peróxido de hidrogênio, oḅ servou que em solos arenosos a contribuição da matéria orgânica variam de 50 a $60 \%$ da CTC do solo, enquanto que em solos ar gilosos essa contribuição era de apenas 30 a $40 \%$. RAIJ (1969) apesar de ter utilizado a mesma técnica, encontrou valores maiores, da ordem de $74 \%$ para as camadas superficiais, o que está ainda mais próximo do observado no presente trabalho.

\subsection{Determinações DE}

Desde a introdução do conceito de $\mathrm{pH}$ na Ciência do Solo e seu uso como medida da atividade do íon $\mathrm{H}^{+}$na solução do solo, uma grande controvérsia foi criada principalmente sobre a validade das interpretações normalmente dadas a essa determinação (COLEMAN et alii, 1951 e PEECH \& MCDEVIT, 1951). A razão de diluição, o potencial de junção líquida e o conteūdo de sais nas amostras de terra são fatores que influenciam essa determinação e provavelmente são os principais responsãveis pela falta de confiança nos resultados obtidos. 
Com a introdução da determinação do pH em solução de $\mathrm{CaCl}_{2}$ 0,0lM por SCHOFIELD \& TAYLOR (1955) esses fatores puderam ser melhor contornados, uma vez que, essa determinação independe da razão diluição, e a suspensão de solo em solü ção de $\mathrm{CaCl}_{2}$ 0,0lM é floculada e portanto, o potencial de junção líquida é minimizado, pois, o eléctrodo de calomelano é mantido no sobrenadante isento de partículas de argila. Alérn disso, as leituras potenciométricas são feitas sempre na mesma concentração salina evitando-se assim, as variações no conteüdo de sais das amostras de terra.

Os resultados de $\mathrm{pH}$ obtidos em três diferentes determinações estão apresentados na Tabela 3. Observou-se que o $\mathrm{pH}$ em $\mathrm{CaCl}_{2}$ 0,01M apresenta um decréscimo médio de 0,6 unida de de pH em relação ao pH em água, o que está próximo aos valo res anteriormente verificados por PEECH (1965), DAVIES (1971) e FASSBENDER (1975). Além disso, foi observado também estreita relação entre os valores de $\mathrm{pH}$ em água e em solução de $\mathrm{CaCl}_{2}$ 0,01M a qual, está representada na Figura 2. Resolvendose a equação de regressão para alguns valores de $\mathrm{pH}$, pode-se observar que as diferenças entre essas duas determinações não é constante, pois, elas vão diminuindo a medida que aumentaram os valores de $\mathrm{pH}$.

Na literatura é normalmente citado que $0 \mathrm{pH}$ em $\mathrm{CaCl}_{2}$ é mais reprodutivel do que $\mathrm{O} \mathrm{pH}$ em água (PEECH, 1965 e DAVIES, 1971). Entretanto, nesse estudo, não foi observado dị ferença em reprodutibilidade entre essas duas determinações, 
Tabela 3. Valores mëdios de quatro repetições do pH em ãgua, cloreto de cálcio 0,01M e SMP, com os respectivos cọeficientes de variação médios das amostras dos so los estudados.

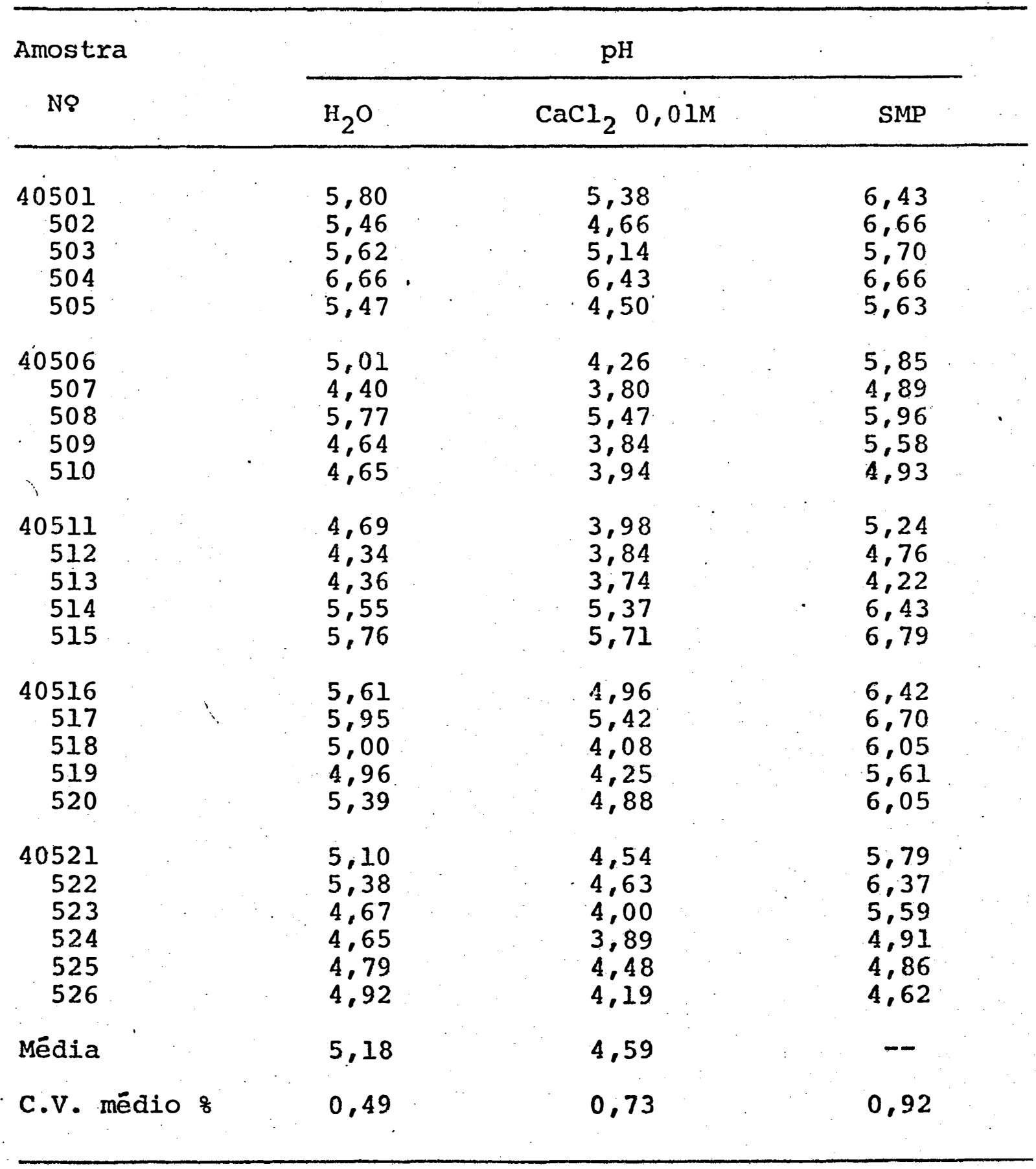




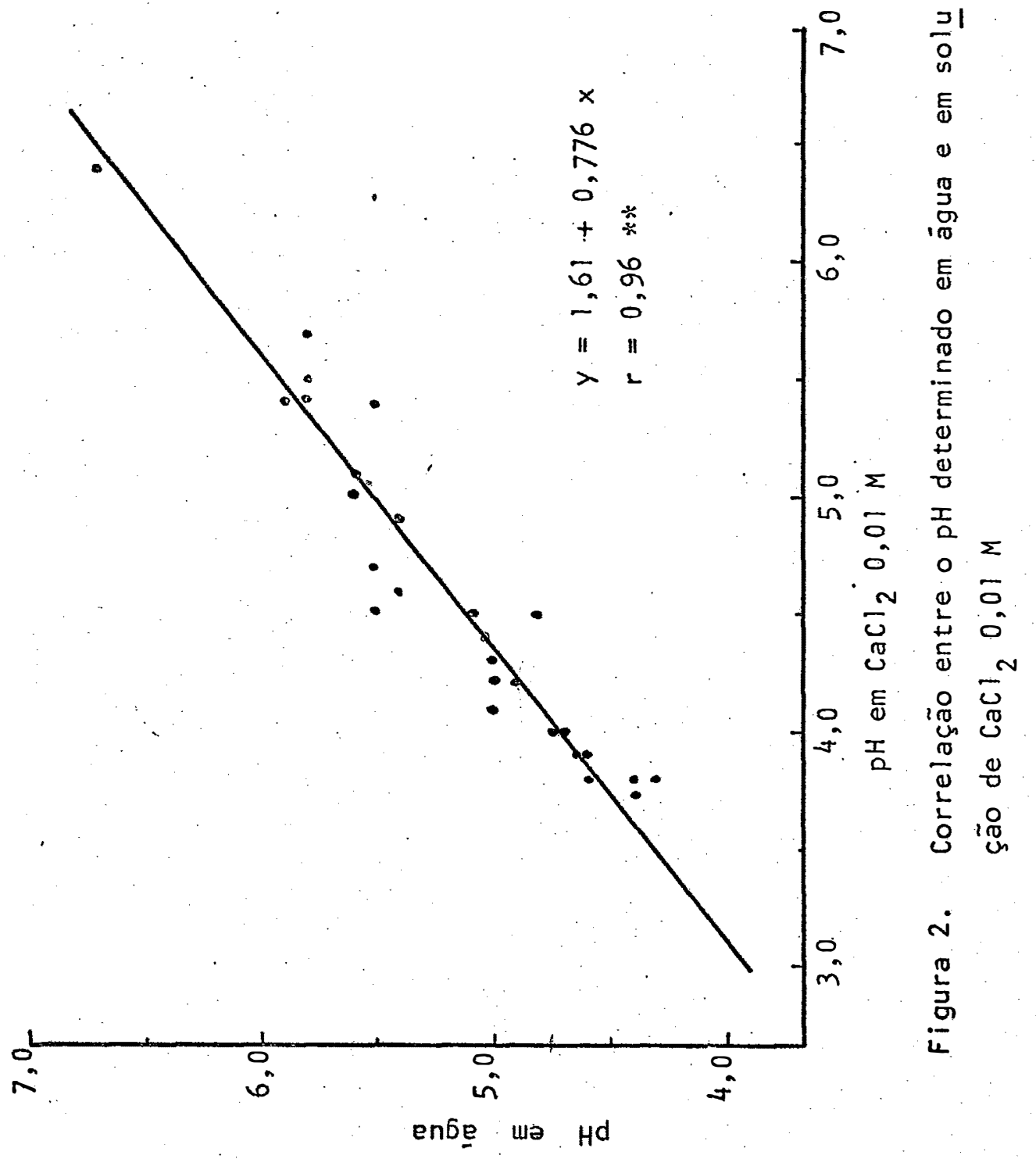


sendo que, o coeficiente de variação mẻdio para $\mathrm{o} \mathrm{pH}$ em água foi de $0,49 \%$ enquanto que para $0 \mathrm{pH}$.em $\mathrm{CaCl}_{2}$ fol de $0,79 \%$. Por outro lado, observou-se que o tempo necessắrio para o equili brio do eléctrodo com a suspensão de solo foi menor para o $\mathrm{pH}$ em $\mathrm{CaCl}_{2}$ em relação ao pH em água. Isso provavelmente acontece por que a suspensão de solo em $\mathrm{CaCl}_{\mathrm{e}} 0$,01M é floculada e, portanto, o sobrenadante normalmente não possue partículas de argila em suspensão. 'Caso não seja aguardado o tempo suficien te para o equilíbrio do eléctrodo com a suspensão de solo, isso poderá contribuir para a diminuição da reprodutibilidade do $\mathrm{pH}$ em ägua.

Os valores do $\mathrm{pH}$ de equilíbrio da solução tampão SMP com o solo também estão representados na Tabela 3 . Diferentemente das determinações de $\mathrm{pH}$ jā apresentadas, que medem a atividade do Ion $\mathrm{H}^{+}$na solução do solo, ou seja., a : acidez ativa, a determinação do pH de equilíbrio de uma solução tampão com o solo é sensível também a sua acidez potencial. Os decréscimos verificados em relação ao pH original da solução tampão, são proporcionais, à acidez potencial dos solos. Por essa razão, essas soluções tampão são geralmente empregadas nos métodos rápidos para determinação da necessidade calagem (WOODRUFF, 1948; SHOEMAKER et alii, 1961 e YUAN, 1974), ou ain da na determinação da acidez potencial dos solos por meio de leituras potenciométricas (BROWN, 1943; ADAMS \& EVANS, 1962 e RAIJ et alii, 1979). Nesses casos torna-se necessārio construir as curvas de calibração com outros métodos nas quais a 
determinação é feita diretamente por titulação de extratos de solos (RAIJ et alii, 1979), ou através de curvas de titulação potenciométrica da solução tampão com ácidos (BROWN, 1943 e ADAMS \& EVANS, 1962).

\subsection{Titulação POTENCIOMÉTRICA DA SOLUÇÃO TAMPÃO SMP COM DIVERSOS ÁCIDOS E SOLOS}

Na Figura 3 estão representadas as curvas de titulação potenciométrica da solução tampão SMP por três ácidos é solos. Essas curvas foram obtidas adicionando-se os volumes dos ăcidos em $5 \mathrm{ml}$ de solução tampão diluídos em $25 \mathrm{ml}$ de água e após o equilíbrio, obtinha-se os valores de $\mathrm{pH}$ correspondentes. No caso dos solos, a equação de regressão da Figura 4 foi plotada na Figura 3 para permitir a comparação entre as forças dos ácidos com a acidez dos solos.

Pode-se notar claramente que a acidez do solo é muito menos ativa do que as dosácidos empregados, porém, apresenta a mesma tendência do cloreto de alumínio e do ácido acético quanto a força do ácido, enquanto que o ácido clorídrico promoveu decréscimos lineares no pH da solução tampão até por volta de $\mathrm{pH} 2,5$, demonstrando o comportamente de ácido forte. Essas curvas são similares às obtidas por MCLEAN et alii(1960) os quais comentaram que uma solução tampão pode ter pequena ca pacidade tampão na presença de um ácido forte como é o caso do ácido clorídrico e por outro lado, apresenta extrema capacidade tampão na presença de solos ácidos. 


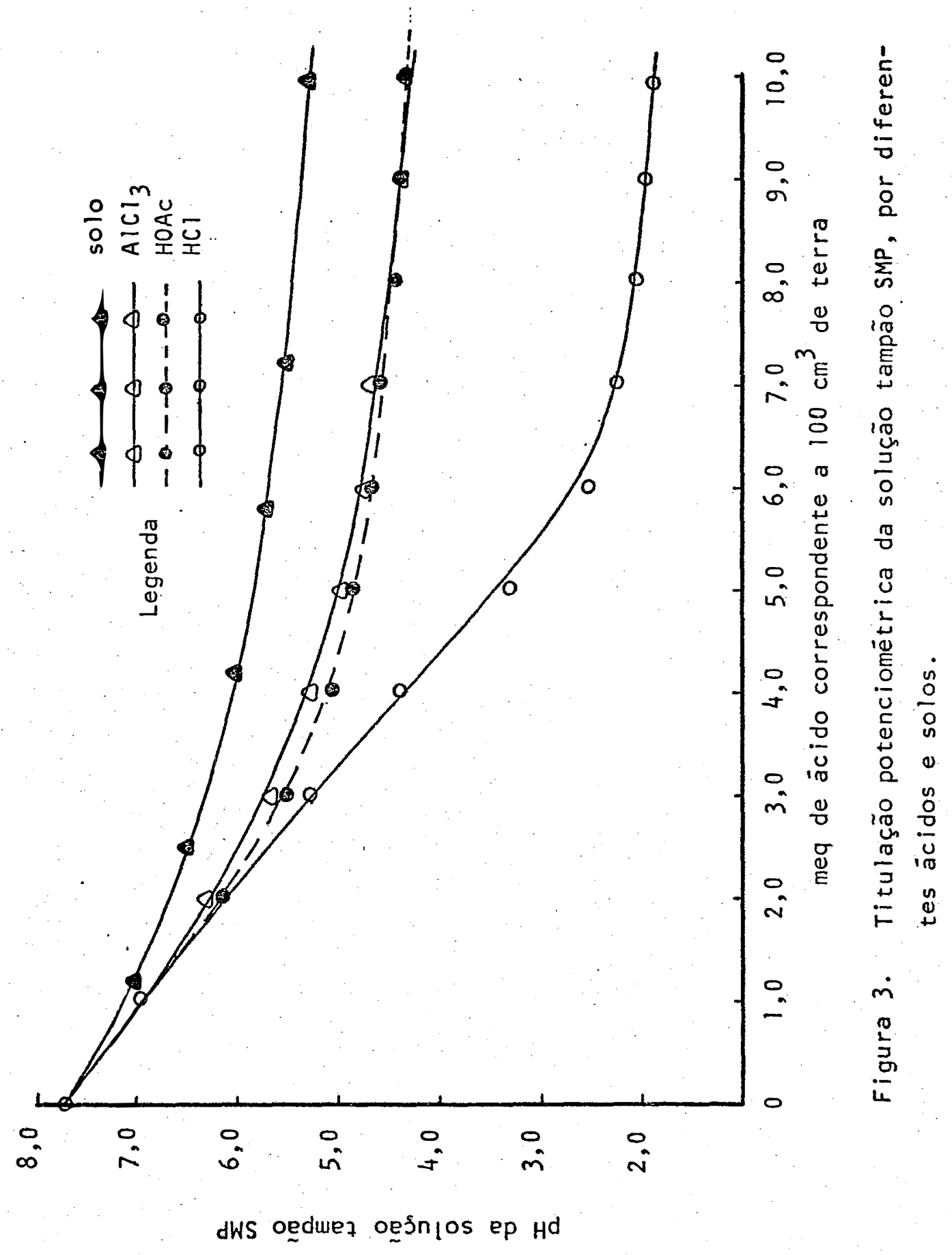


Esse comportamento de soluções tampão deve ser considerado na adaptação e calibração de métodos tampões para os solos de uma região. FREITAS et alii (1968) adaptaram o mé todo SMP para os solos do Estado de São Paulo, propondo a rela ção de 5:5:20 entre solo-ãgua-tampão, a qual utiliza o dobro da quantidade de tampão em relação ao método SMP original, que utiliza a relação 5:5:10. Essa modificação provocou a diminui ção da sensibilidade do método devido ao aumento da capacidade tampão da solução SMP em relação ao solo. Por outro lado, os estudos feitos por RAIJ et alii (1979) mostraram que a relação que melhor sensibilidade apresentava para os solos do mesmo es tado era a relação 10:20:10, ou seja, com a metade de tampão utilizado em relação a quantidade de terra usada no métọo SMP original.

\subsection{RELAÇÃO ENTRE A ACIDEZ POTENCIAL DO SOLO E O PH DA SOLUC,ÃO TAMPÃO SMP}

Uma relação entre os valores de $H+A l$ extraídos pelo método do acetato de cálcio (CATANI \& GALIo, 1955) com o pH de equilíbrio da solução tampão SMP com o solo, na relação 10:20:10 entre solo-ägua e tampão foị apresentada recentemente no trabalho de RAIJ et alii (1979). Os autores admitem a possibilidade de se determinar os teores de $\mathrm{H}+\mathrm{Al}$ do solo atravẹs da leitura do pH da solução tampão SMP, após o equilíbrio com a acidez potencial do solo. Para tanto utiliza-se a equação de regressão $y=28,8-4,18 x(x=-0,975)$, na qual $y$ é 
igual aos valores de $\mathrm{H}+\mathrm{Al}$ em meq $/ 100 \mathrm{~cm}^{3}$ de terra e $\mathrm{x}$ é $\circ \mathrm{pH}$ SMP. Essa equação permite a determinação de valores de $\mathrm{H}+\mathrm{Al}$ de até $8 \mathrm{meq} / 100 \mathrm{~cm}^{3}$ de terria, uma vez que, os autores não utilizaram solos de elevada CTC nesse estudo.

Noupresente trabalho, selecionou-se uma população de solos com maior amplitude de variação nos valores de cạ pacidade de troca catiônica e obteve-se uma nova equação de re gressão, a qual, está apresentada na Figura 4. Os teores de H + Al utilizados no cálculo dessa equação foram determinados pelo método da extração com acetato de cálcio normal a pH 7,0 (CATANI \& GALLO, 1955), enquanto que $\circ \mathrm{pH}_{\mathrm{SMP}}$ foi determinado apōs $\bigcirc \mathrm{pH}$ em água na relação 10:25:5. Esta técnica apresenta grande sensibilidade até o ponto de inflexão da curva de calibração que ocorre por volta de $12 \mathrm{meq}$ de $(\mathrm{H}+\mathrm{Al}) / 100 \mathrm{~cm}^{3}$ de terra, e perde um pouco da sensibilidade na fase exponencial da curva, embora permitindo ainda a determinação de $\mathrm{H}+\mathrm{Al}$ até vâ lores de $30 \mathrm{meq} / 100 \mathrm{~cm}^{3}$ de terra com precisão suficiente. Pode -se apontar algumas vantagens desse método em relação ao método titulométrico da extração com acetato de cálcio normal . à pH 7,0: a) é um método bástante simples e muito mais rápido do que o titulométrico, portanto, è mais adaptável : às condições de laboratórios de rotina que realizam um grande número de análises diariamente; b) a extração com acetato de cálcio requer o preparo diário dessa solução a qual è muito influenciada pela qualidade da droga utilizada; c) com os testes de reprodutibilidade realizados com quatro repetições obteve-se 


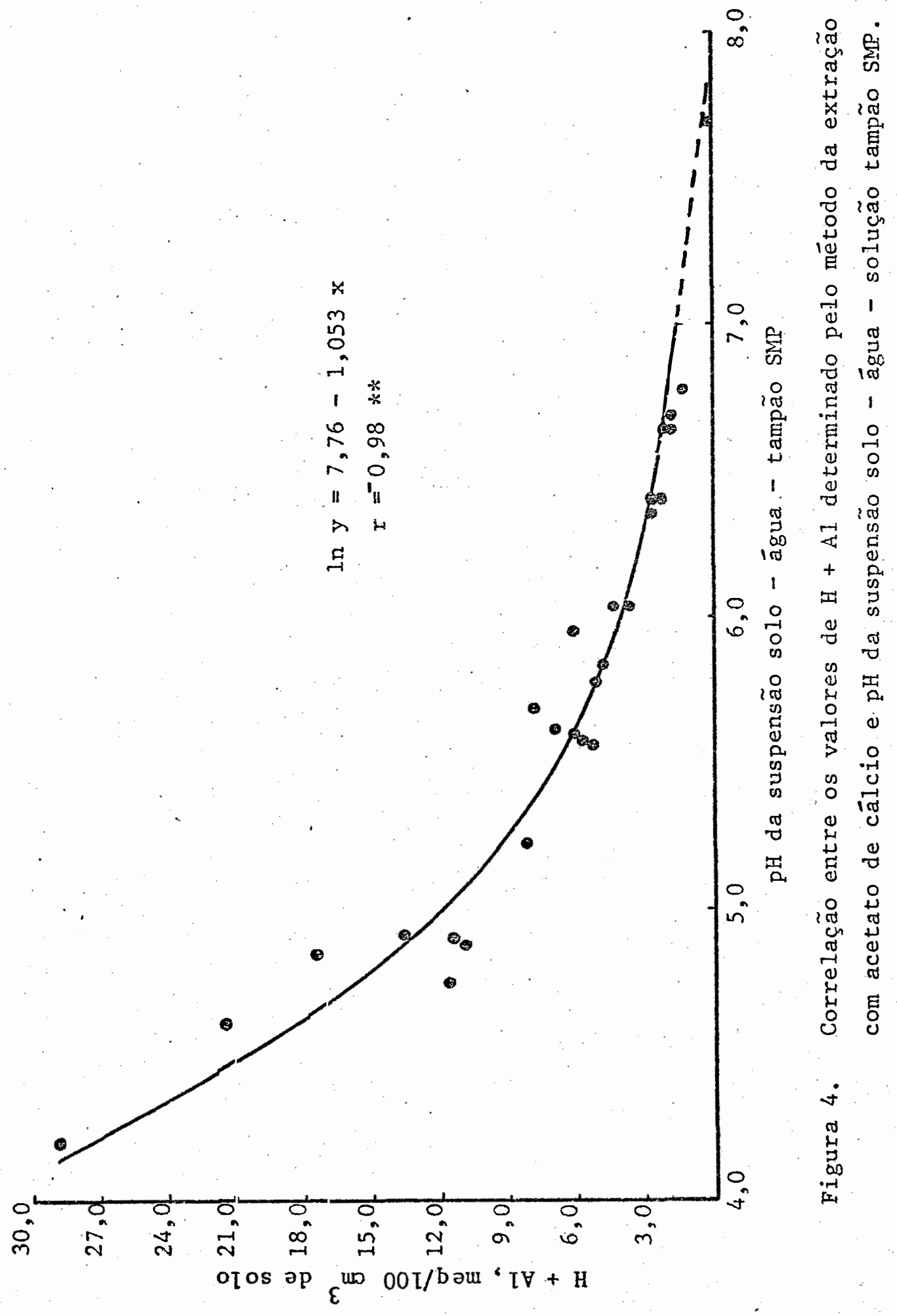


um coeficiente de variação médio para o processo titulométrico de $8,3 \%$, enquanto que pelo método proposto obteve-se um coeficiente de variação médio de 5,6, portanto, è mais reprodutível do que o processo titulométrico.

\subsection{DETERMinACAOO DOS TEORES DE $\underline{H}+\underline{A L}$ DO SOLO ATRAVÉS DE LEITURA POTENCIOMÉTRICA DO PH}

Trata-se de uma determinação bastante simples, cujo procedimento consiste em medir $10 \mathrm{~cm}^{3}$ de terra e adicionar $25 \mathrm{ml}$ de água ou solução de $\mathrm{CaCl}_{2}$ 0,01M e obter-se desse modo, os valores de $\mathrm{pH}$ correspondentes em água ou em $\mathrm{CaCl}_{2}$. Adiciona-se $5 \mathrm{ml}$ de solução tampão SMP com concentração dobrada em re lação a proposta originalmente por SHOEMAKER et alii (1961). A suspensão é agitada durante 15 minutos e após o periodo de repouso de 60 minutos necessários para o estabelecimento do equi líbrio faz-se a leitura potenciométrica e obtem-se $\circ \mathrm{pH}_{\mathrm{SMP}}$ • Com esse valor de $\mathrm{pH}$, resolve-se a equação de regressão da Figura 4 e os teores de $\mathrm{H}+\mathrm{Al}$ são obtidos por cálculo e jã expressos em meq $/ 100 \mathrm{~cm}^{3}$ de terra.

Ao teor de $\mathrm{H}+\mathrm{Al}$ soma-se o valor da soma de bases $(\mathrm{Ca}+\mathrm{Mg}+\mathrm{K})$ obtendo-se a estimativa da CTC do solo pelo método indireto, que poderá ser utilizada no cálculo na satura ção de bases aplicando-se a fórmula Vơ = S . 100/T (HISSINK, 1924).

Os dádos da Tabela 4 permitem a comparação entre as determinações de $\mathrm{H}+\mathrm{Al}$, CTC e saturação de bases do solo 
Tabela 4. Comparação entre os valores de $\mathrm{H}+\mathrm{Al}$, capacidade de troca de cations e saturação de bases, obtidos pelo método da extração com acetato de călcio e o método proposto neste trabalho.

\begin{tabular}{|c|c|c|c|c|c|c|}
\hline \multirow{2}{*}{$\begin{array}{c}\text { Amostras } \\
\text { No }\end{array}$} & \multicolumn{2}{|c|}{$\mathrm{H}+\mathrm{Al}$} & \multicolumn{2}{|c|}{ C.T.C. } & \multicolumn{2}{|c|}{ V8 } \\
\hline & $\mathrm{Ca}(\mathrm{OAC})_{2}$ & $\begin{array}{c}\text { Método } \\
\text { proposto }\end{array}$ & $\mathrm{Ca}(\mathrm{OAC})_{2}$ & $\begin{array}{c}\text { Método } \\
\text { proposto }\end{array}$ & $\mathrm{Ca}(\mathrm{OAC})_{2}$ & $\begin{array}{l}\text { Método } \\
\text { proposto }\end{array}$ \\
\hline . & $--\infty-\infty-\infty$ & $\mathrm{meq} / 100 \mathrm{~cm}$ & $n^{3}$ de solo & ----- & $---1--\frac{9}{8}$ & $--\infty---\infty-\infty$ \\
\hline $\begin{array}{r}40501 \\
502 \\
503 \\
504 \\
505\end{array}$ & $\begin{array}{l}2,83 \\
2,04 \\
8,09 \\
2,26 \\
7,17\end{array}$ & $\begin{array}{l}2,70 \\
2,12 \\
5,92 \\
2,12 \\
6,30\end{array}$ & $\begin{array}{r}5,91 \\
3,09 \\
16,31 \\
15,76 \\
9,54\end{array}$ & $\begin{array}{r}5,78 \\
33,17 \\
14,14 \\
15,62 \\
8,67\end{array}$ & $\begin{array}{l}52,1 \\
34,0 \\
50,4 \\
85,6 \\
24,8\end{array}$ & $\begin{array}{l}53,3 \\
33,1 \\
58,1 \\
86,4 \\
27,3\end{array}$ \\
\hline $\begin{array}{r}40506 \\
507 \\
508 \\
509 \\
510\end{array}$ & $\begin{array}{r}5,03 \\
11,12 \\
6,21 \\
5,50 \\
13,61\end{array}$ & $\begin{array}{r}5,01 \\
13,70 \\
4,44 \\
6,68 \\
13,12\end{array}$ & $\begin{array}{r}6,27 \\
11,63 \\
18,46 \\
5,95 \\
14,29\end{array}$ & $\begin{array}{r}6,25 \\
14,21 \\
16,69 \\
7,13 \\
13,80\end{array}$ & $\begin{array}{r}19,8 \\
4,4 \\
66,4 \\
7,6 \\
4,7\end{array}$ & $\begin{array}{r}19,8 \\
3,6 \\
73,4 \\
5,3 \\
4,9\end{array}$ \\
\hline $\begin{array}{r}40511 \\
512 \\
513 \\
514 \\
515\end{array}$ & $\begin{array}{r}8,39 \\
11,80 \\
28,86 \\
2,43 \\
1,45\end{array}$ & $\begin{array}{r}9,46 \\
15,68 \\
27,64 \\
2,67 \\
1,86\end{array}$ & $\begin{array}{r}9,83 \\
12,27 \\
29,46 \\
6,78 \\
5,02\end{array}$ & $\begin{array}{r}10,90 \\
16,15 \\
28,24 \\
7,02 \\
5,43\end{array}$ & $\begin{array}{r}14,6 \\
3,8 \\
2,0 \\
64,1 \\
71,1\end{array}$ & $\begin{array}{r}13,2 \\
2,9 \\
2,1 \\
62,0 \\
65,7\end{array}$ \\
\hline $\begin{array}{r}40516 \\
517 \\
518 \\
519 \\
520\end{array}$ & $\begin{array}{r}2,87 \\
1,95 \\
3,83 \\
6,34 \\
4,51\end{array}$ & $\begin{array}{l}2,73 \\
2,03 \\
4,07 \\
6,42 \\
4,05\end{array}$ & $\begin{array}{l}5,88 \\
6,34 \\
4,70 \\
8,92 \\
8,69\end{array}$ & $\begin{array}{l}5,74 \\
6,42 \\
4,94 \\
9,00 \\
8,23\end{array}$ & $\begin{array}{l}51,2 \\
69,2 \\
18,5 \\
28,9 \\
48,1\end{array}$ & $\begin{array}{l}52,4 \\
68,4 \\
17,6 \\
28,7 \\
50,8\end{array}$ \\
\hline $\begin{array}{r}40521 \\
522 \\
523 \\
524 \\
525 \\
526\end{array}$ & $\begin{array}{r}5,32 \\
2,86 \\
5,9 \cdot 1 \\
11,59 \\
17,49 \\
21,50\end{array}$ & $\begin{array}{r}5,30 \\
2,89 \\
6,59 \\
13,50 \\
14,11 \\
18,23\end{array}$ & $\begin{array}{r}8,94 \\
5,23 \\
6,69 \\
12,34 \\
24,22 \\
25,69\end{array}$ & $\begin{array}{r}8,92 \\
5,26 \\
7,37 \\
14,25 \\
20,84 \\
21,42\end{array}$ & $\begin{array}{r}40,5 \\
45,3 \\
11,6 \\
6,1 \\
27,8 \\
12,9\end{array}$ & $\begin{array}{r}40,6 \\
45,0 \\
10,6 \\
5,3 \\
32,3 \\
14,9\end{array}$ \\
\hline CV mëdio & 8,30 & 5,60 & - & - & - & - \\
\hline
\end{tabular}


obtidos pelo mëtodo do acetato de cálcio e pelo método proposto. Pode-se notar que os desvios observados entre os resultados obtidos pelo método proposto em relação ao método do aceta to de cālcio são pequenos e podem ser despresiveis com a aplicação que se pretende dar aos resultados que è a recomendação de calagem com base na correlação entre 0 pH e saturação de ba sẹ.

4.6 RELAÇ̃̃ES ENTRE. O PH E CÄTIONS TROCÁVEIS NO SOLO.

4.6.1 Estabelecidas com base na CTC A PH 7,0

Na Figura 5 estão representadas as correlações com as respectivas equações de regressão obtidas entre $0 \mathrm{pH}$ em àgua e saturação de bases. Elas foram calculadas com base na CTC determinada indiretamente somando-se as bases trocäveis aos teores de $\mathrm{H}+\mathrm{Al}$ determinados pelo método da extração com acetato de cálcio (Figura $5 a$ ) e pelo método proposto (Figurá 5b). As equações de regressão obtidas são idênticas, o que de monstra que os mêtodos de determinação de $\mathrm{H}+\mathrm{AJ}$ fornecem resultados semelhantes, para os solos estudados.

Nessas figưras estão representados tambêm os intervalos de confiança para a estimativa do $\mathrm{pH}$ em função do grau de saturação de bases no solo.. As correlações da Figu ra 6 diferem das da Figura 5 apenas nos valores de $\mathrm{pH}$ que foram determinados em $\mathrm{CaCl}_{2}$. Observa-se que as correlações obti das com $\circ \mathrm{pH}$ em $\mathrm{CaCl}_{2}$ são mais estreitas do que as obtidas com 

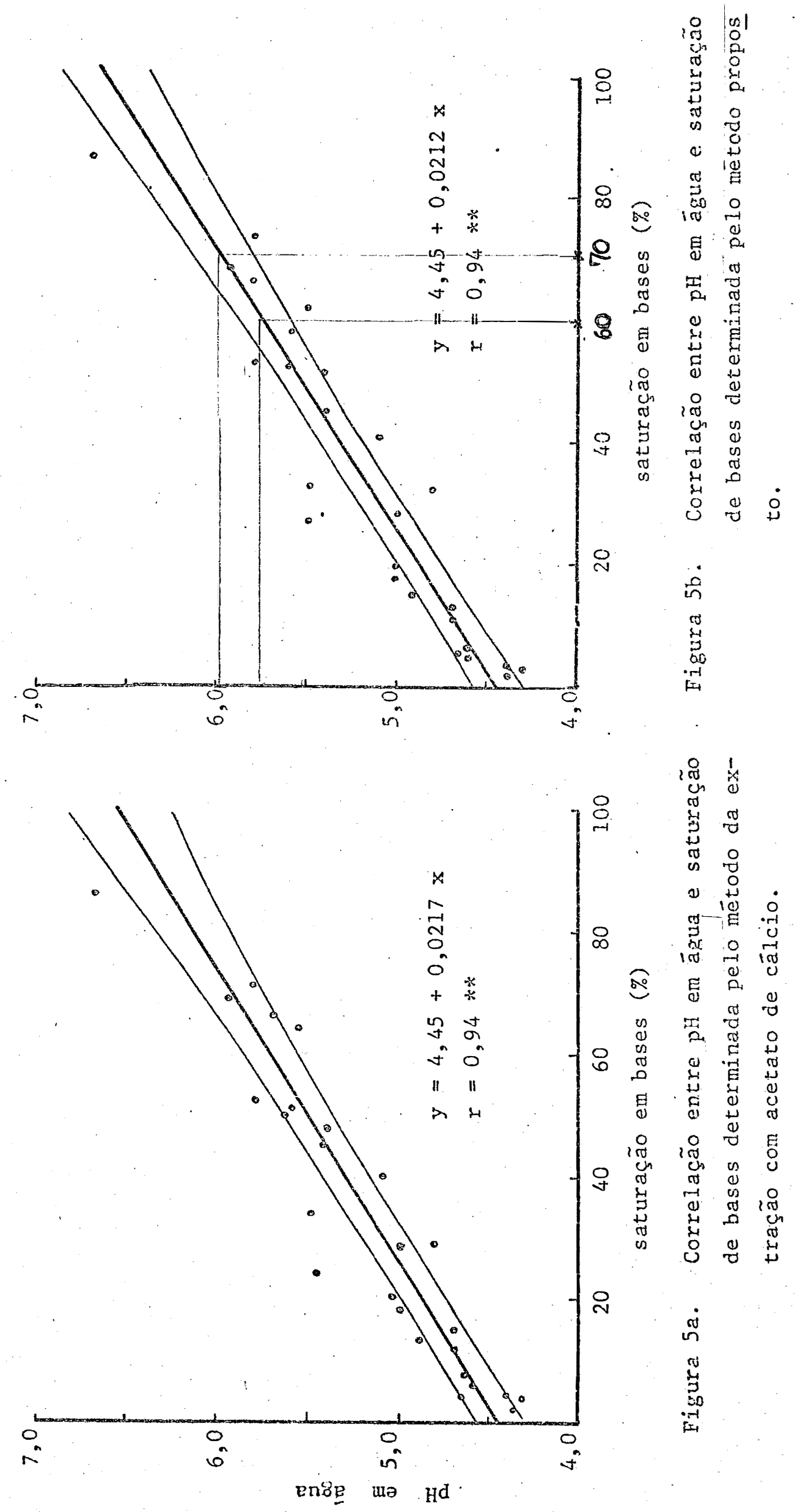
- pH em ägua, o que demonstra que a determinação do pH em $\mathrm{CaCl}_{2}$ ê mais precisa do que a determinação em ågụa. Esses resultacos concordam com os de CAMARGO \& RAIJ (1975) e CASTRO et alii (1972) que mostraram que o pH em $\mathrm{CaCl}_{2}$ possue correlação mais estrejta com o grau de saturação de bases do solo do que o pHI en ågua (Tabela 5).

Entre as razões para a maior precisão da ceterni nação o pH em $\mathrm{CaCl}_{2}$, algumas delas jä discuttdas anteriormente, porëm, vale a pena ressaltar que a eliminação da influência da concentraçäo de sais nas amostras de terra ex provavelmente a pxincipal responsävel. por conseguinte, a eliminação da influência de sais diminue as variações sazonais do pH fCoIIINS. et alii, 1970) que contribuen sensivelmente para a falta de confiablifiade aos valores de $\mathrm{pH}$.

A correlação entre 0 pH e saturaçäo de bases no solo, mostra que o $\mathrm{pH} \ddot{e}$ una função da quantidade de bases trocäveis existentes no solo e, portanto, ela pode ser utilizada como parâmetro ou critêrio de recomendação de calagem. Apesar de que, COLEMAN \& MEHLICH (1957) mostraram que solos com predo minio de argila montmorilonita no complesso de troca apresentaram correlação entre o $\mathrm{pH}$ e saturação de bases diferente em re lação a solos com predominio de caulinita ou com CTC dependente principalmente da fração orgânica. Tudo indica que, para as condições brasileiras ou, mais especificamente para as condições dos solos do Estado de são paulo, onde jā existe um maior nưmero de equações de regressão jā traçadas, essa corre- 

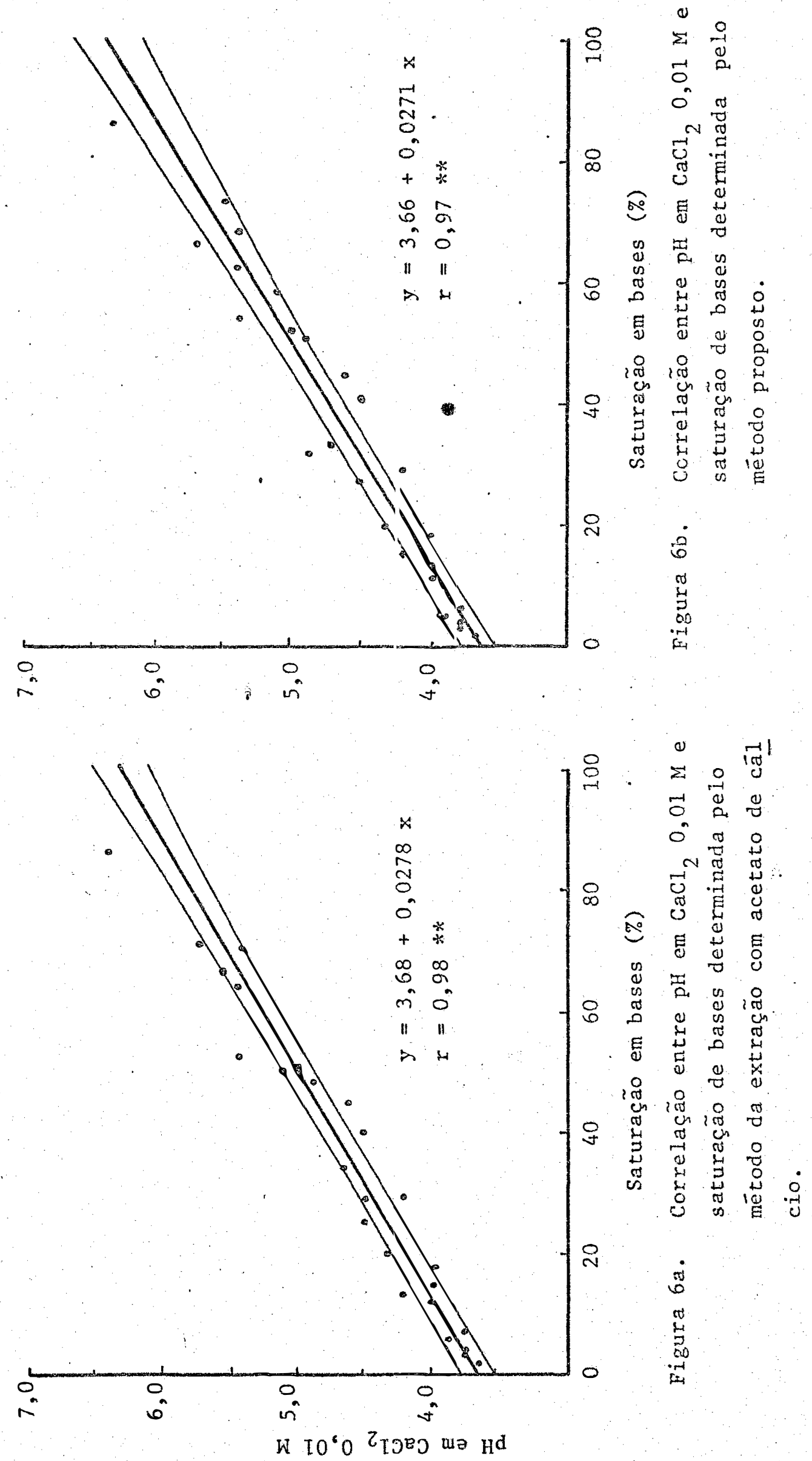
lação é muito consistente como pode ser visto na Tabela 5 . ES sa semelhança entre as equações de regressão vem reforçar a se gurança de utilizar-se a correlaçäo entre $\circ \mathrm{pH}$ e o grau de saturação de bases como critério de recomendação de calagem, jă que com esse critërio consegue-se atingìr nîveis de calagem com bastante rigor.

Na tentativa de se avaliar a representatividade das amostras utilizadas em relação aos solos do Estado de São Paulo, fez-se uma nova amostragem, totalmente casualizada em amostras de agricultores enviadas para anālise na Seção de Fer tilidade do Solo do Instituto Agronômico. A amostragem totalí zou 130 amostras para as quais foi traçada outra equação de re gressao entre $\mathrm{opH}$ e saturação de bases, que estä representada na Figura 7. Pode-se notar que a equação de régressão obtida é muito semelhante a da Figura 5, o que mostra que a população de solos anteriormente selecionada, de certo modo, representa bem os solos do Estaḍo de São Paulo.

\subsubsection{Estabelecidas com base na CTC efetiva}

$$
\text { COLEMAN et alii (1959) definiram a CTC efetiva }
$$
do solo como sendo a capacidade mâxima de retenção de câtions que o solo apresenta ao seu pH atual. Ela ë normalmente deter minada pelo somatörio de câtions extraídos por uma solução de sal neutro não tamponado, sendo que, o mais empregado $\bar{e} \circ$ $\mathrm{KCl}$ 1N. Nos mesmos trabalhes, os autores reforçaram a importância dessa determinação, inferindo que ela representava a 
Tabela 5. Equações de regressão e coeficientes de correlação entre $\circ \mathrm{pH} \in$ saturação de bases do solo, obtidas por vários autores.

$\begin{array}{lll}\text { Equação de regressão } & \begin{array}{l}\text { Coeficiente } \\ \text { de correlação }\end{array} & \text { Referência }\end{array}$

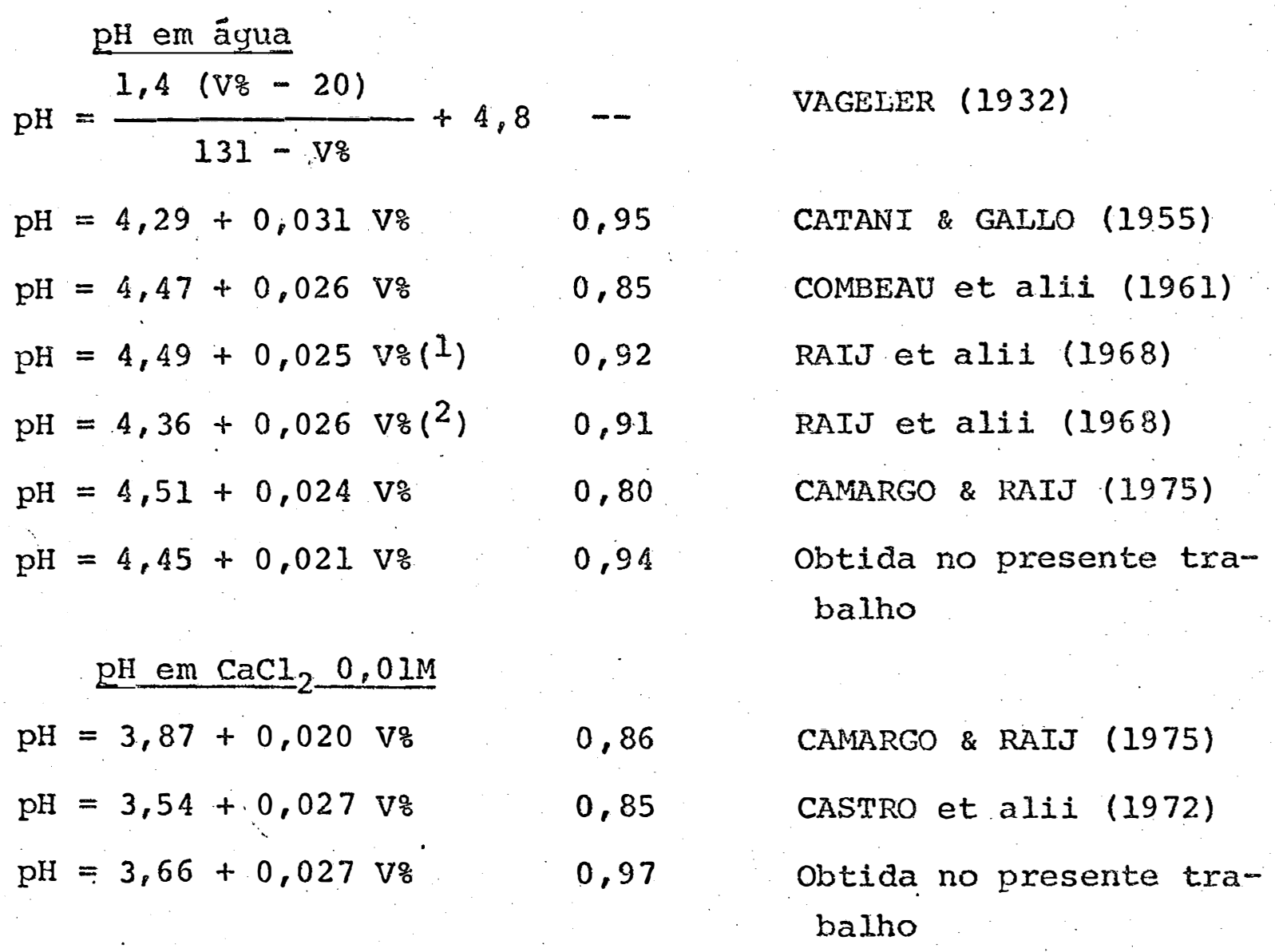

(I) Obtida com amostras superficiais de solos em horlzonte B latossölico.

(2) Obtida com amostras superficiais de solos com horizonte $B$ textural. 


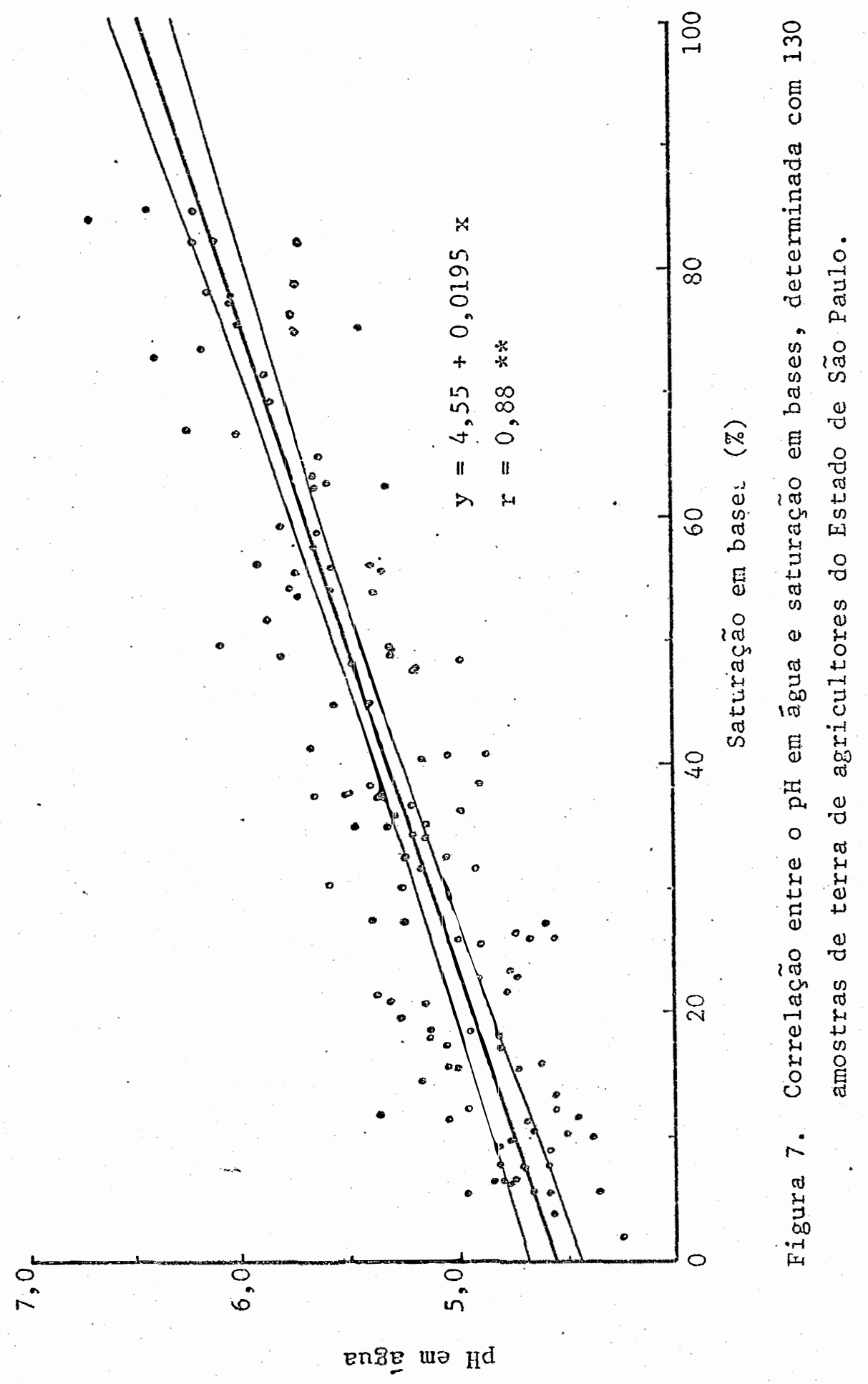


quantidade de cargas negativas permanentes do complexo de troca. Essa afirmação foi retificada em um trabalho posterior (COLEMAN et alii, 1964), uma vez que, nos trabalhos anteriores os autores não observaram que a fração orgânica e os sesqujöxidos de ferro e-aluminjo tambēm contribuian para a CTC efetiva do solo e no entanto, apresentam cargas negativas dependentes do $\mathrm{pH}$.

No presente trabalho procurou-se estabelecex cor relações entre os valores de $\mathrm{pH}$ e cátions trocáveis com "base na CTC efetiva dos solos. Nas figuras $8 \mathrm{a}$ e $8 \mathrm{~b}$ estão representadas as equações de regressão obtilas entre $\mathrm{opH}$ em água e em $\mathrm{CaCI}_{2} 0,01 \mathrm{M}$ com a saturação de alumínio, respectivamente. Observa-se que para o valor de $\mathrm{pH}$ em ägua de 5,4 e en $\mathrm{CaCl}_{2}$ de 4,8 o aluminio è totalmente neutralizado, sendo que, esses valores confirmam exatamente os resultados de-CAMARGO \& RAIJ (1975) e está próximo ao valox 5,6 para o pH em água, obtido pOI CATANI \& ALONSO (1969).

Com base nesses resultados, pode-se dizer, ainda, que $\circ$ uso do aluminio trocāvel como cxitërio de recomendaçăo de calagem (KAMPRATH, 1970) não permite a recomendação de cala gem em niveis superiores a esses valores de pli.

Por outro lado, as correlações entre os valores de pH e saturação de bases calculadas em flinção dä CTC efetiva do solo $\left.\left(V \%=S / S+A I^{3}\right)\right)$ são diferentes das correlações obtidas com a saturação de bases calculadas com os valores de CTC medidos a pH 7,0, e elas tambëm não permitem o cálculo da cala 

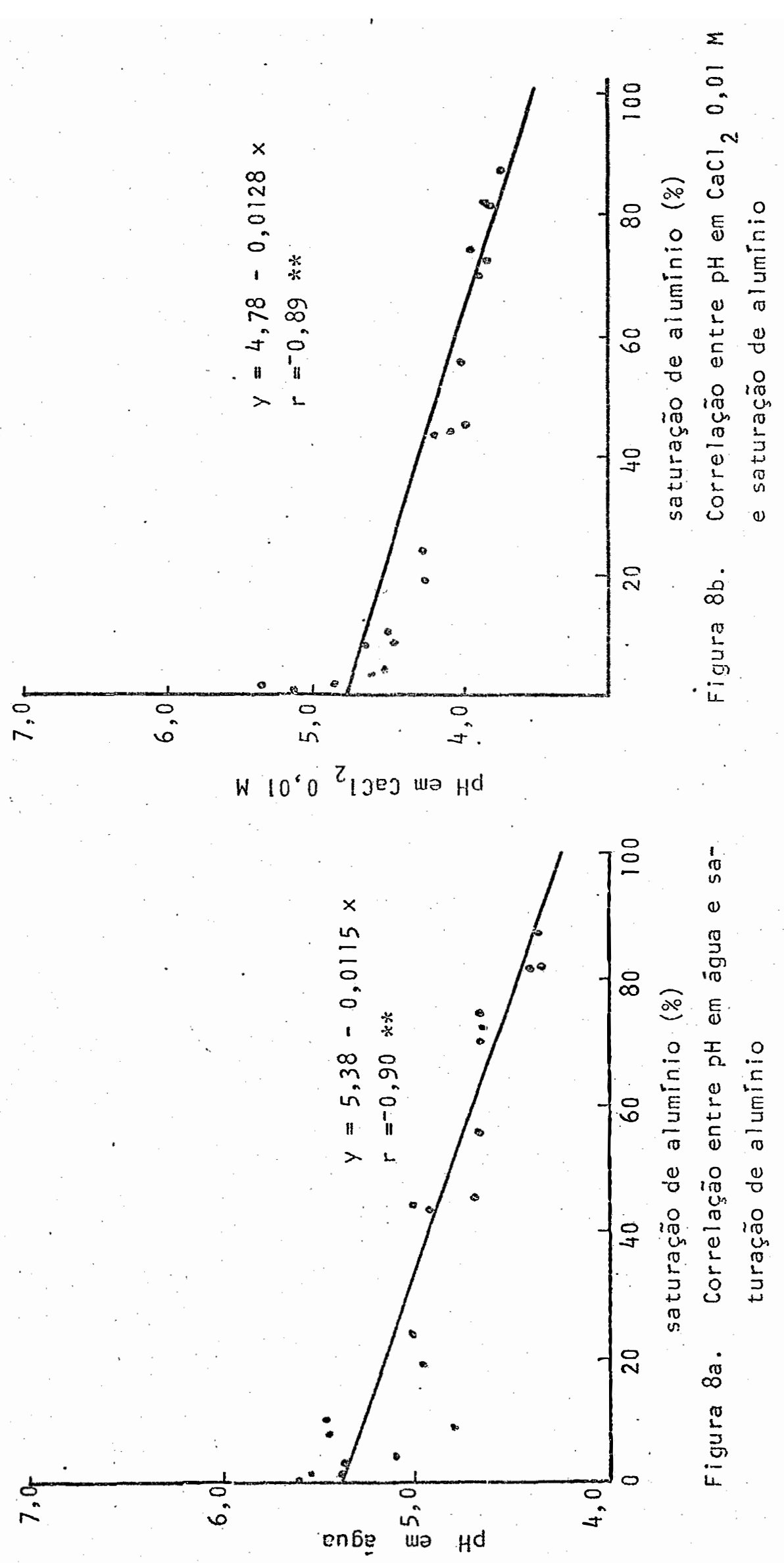
gem para níveis superiores a $\mathrm{pH} 5,4$, quando dererminado em àgua, ou $\mathrm{pH} 4,8$ para a determinação èm solução de $\mathrm{CaCl}_{2} 0,01 \mathrm{M}$ (figuras $9 a$ e 9b).

Portanto, pode-se dizer que o critério do aluminio trocável ë incomplero, uma vez que, acima dessas faizas de pH torna-se inaplícável, principalmente quaudo asscciado com o critērio complementar que procura garantix os teores de cälcio mais magnésio a valores prë-determinados: perdendo desse modo. o controle do $\mathrm{pH}$.

\subsection{EVOLUÇÃO DAS FÓRMULAS PARA O CALCULO DA CALAGEM COM BASE NA SATURAÇÃO DE BASES DO SOLO}

Uma expressão para o cälculo da mecessidade de calagem foi introduzida no Brasil por VAGELER (1932) que, ba-seado provavelmente nos estudos de HISSINR (1924), deduziu a seguinte fórmula para o călculo da calagem para pH 7,0:

$$
N C=(0,9 \mathrm{~T}-\mathrm{S}) \times \mathrm{a}
$$

onde:

$$
\begin{aligned}
& N C \text { necessidade de calagem expressa em quilo equivalente } \\
& \text { de cálcio, nas formas de } \mathrm{Ca}(\mathrm{OH})_{2} \text { ou } \mathrm{CaCO}_{3} \\
\mathrm{a}= & \text { profundidade do solo em centimetros } \\
\mathrm{T}= & \text { capacidade de troca de cátions } \\
\mathrm{S}= & \text { soma de bases }
\end{aligned}
$$

O autor apresentava fórmulas também para pH 5,75

e pH 8,0. Alëm di’sso, ele apresentou uma correlação entre pH 

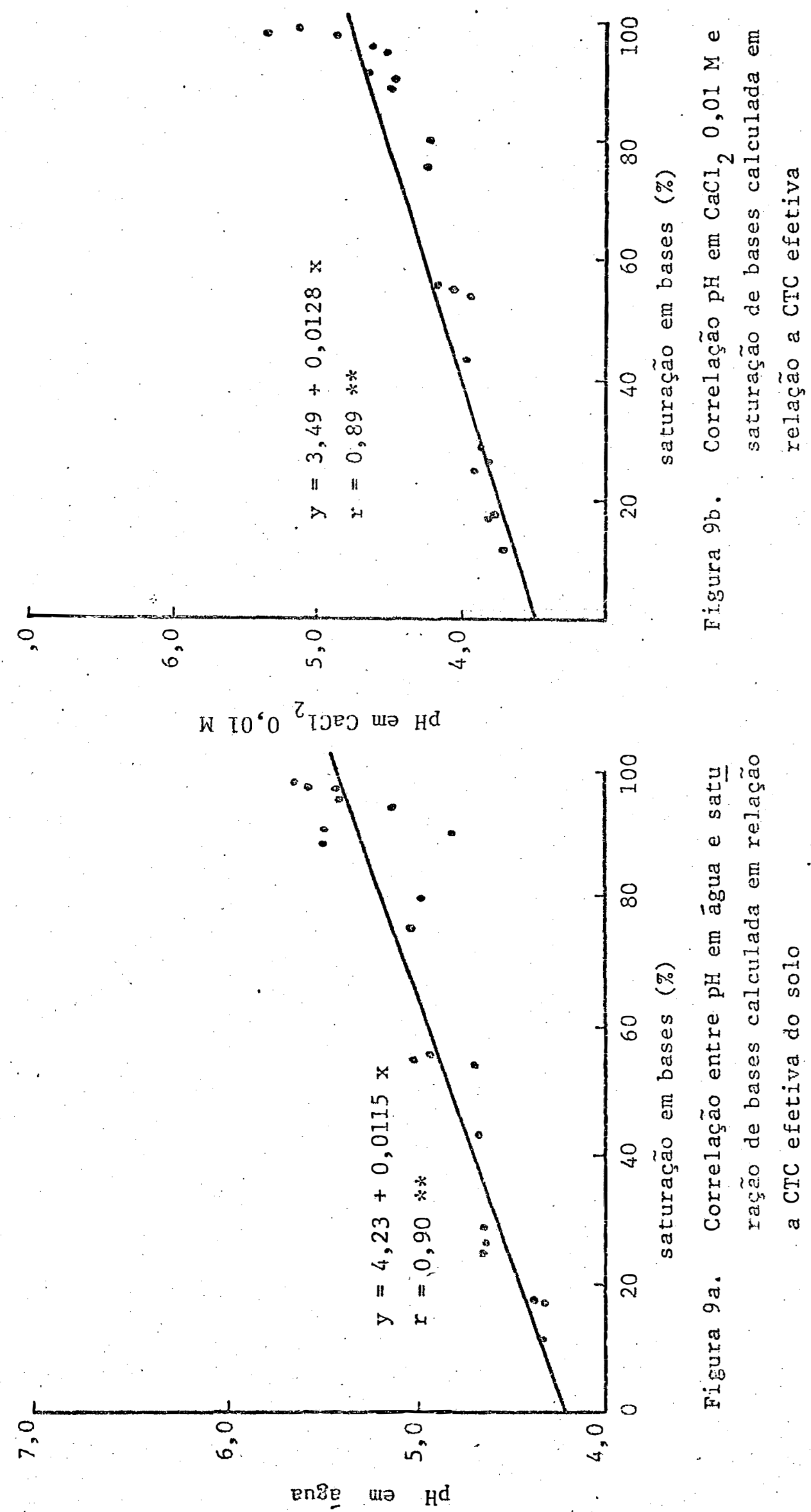
e saturação de bases (Tabela 5), que apesar de ter sido obtida na Alemanha, fornece resultados semelhantes às traçadas com os solos do Estado de São Paulo.

Posteriormente, CATANI \& GALLO (1955) deduziram outra fốrmula para o cálculo da dose de calcário, porém, utilí zando os teores de $\mathrm{H}+\mathrm{Al}$ e saturação de bases:

$$
N C=H \frac{\left(i_{2}-i_{1}\right)}{\left(1-i_{1}\right)}
$$

onde:

$$
\begin{aligned}
\mathrm{NC}= & \text { necessidade de calagem em } \mathrm{t} / \mathrm{ha} \text { de } \mathrm{CaCO}_{3} \text { por } 20 \mathrm{~cm} \text { de } \\
& \text { profunäidade } \\
\mathrm{H}= & \text { teores de } \mathrm{H}+\mathrm{Al} \text { em meq } / \mathrm{l} 00 \mathrm{~g} \text { de terra } \\
i_{2}= & \text { saturação de bases desejada }(70 \%) \\
i_{1}= & \text { saturação de bases atual do solo }
\end{aligned}
$$

MALAVOLTA (1976) deduziu uma förmula simples para o cálculo da calagem, porēm, fixando a saturação de bases em $85 \%$. Sua förmula utiliza apenas os teores de $H+A l$, deter minados pela extração com acetato de cálcio, e a CTC do solo:

$$
I=H+A I-0,15 T
$$

onde:

$$
\begin{aligned}
L & =\text { necessidade de calagem } t / \mathrm{ha} \times 20 \mathrm{~cm} \\
T & =\text { capacidade de troca de câtions } \\
0,15 & =\text { fator que fixa } V=85 \%(1,0-0,85=0,15)
\end{aligned}
$$

No presente trabalho deduziu-se uma nova fórmula para o cálculo da calagem, relacionando-se a necessidade de ca 
lagem com a CTC e saturação de bases no solo, incluindo-se tam bém, o "fator de calagem" para a correção da qualidade do corretivo a ser empregado:

$$
N C=\frac{T\left(V_{2}-V_{1}\right)}{100} \times f
$$

onde:

$$
\begin{aligned}
\mathrm{NC}= & \text { necessidade de calagem expressa em meq de } \mathrm{CaCO}_{3} / \\
& 100 \mathrm{~cm}^{3} \text { de terra, ou } t / \mathrm{ha} \times 20 \mathrm{~cm} \text { de profundidade } \\
\mathrm{T}= & \text { capacidade de troca de cátions, expressa em meq/ } \\
& 100 \mathrm{~cm}^{3} \text { de terra } \\
\mathrm{V}_{1}= & \text { saturação de bases atual do solo, } \% \\
\mathrm{~V}_{2}= & \text { saturação de bases que pretende-se alcançar no so- } \\
& 10, \% \\
\mathrm{f}= & \text { fator de calagem }(E=100 / \mathrm{RRNT})
\end{aligned}
$$

Todas essas förmulas devem conduzir para o mesmo resultado, mantendo-se evidentemente constantes o nivel de calagem e a profundidade do solo que pretende-se corrigir. Contudo, ainda sobre a deđução dessas fórmulas, é interessante no. tar que a förmula de MALAVOLTA (1976) apesar de basear-se no conceito de "insaturação" de bases, è semelhante a förmula de VAGELER (I932), porém, essa última utiliza o concelto de saturação de bases.

4.8 NECESSIDADE DE CALAGEM DETERMINADA POR DIVERSOS MÉTO DOS

Os dados da Tabela 6 permitem a comparação entre 
a recomendação de calagem feita pelo método do acetato de câlcIo (CATANI \& GALIO, 1955) com o método proposto nesse traba-tho. Observa-se que, com base na recomendação média das amostras estudadas, pode-se dizer que os dois métodos são idênticos, uma vez rue, eles diferem entre si apenas na maneira de se deteminat o $\mathrm{H}+\mathrm{Al}$, e alëm disso, a detreminação de $\mathrm{H}+\mathrm{AI}$ pelo método proposto ê calibrada contra o mëtodo do acetato de cälcio. Com relação aindo ao mëtodo de CATANI \& GAILO (1955). haverão alguns desvios em relação ao mêtodo proposto quando se estabelecer o nînel de calagen através do pH ao invës da satum raçäo de bases, pois existe pequena difetença entre a correlacão entre o pil e saturação de bases estabejecias por ciranI * GAlso (1955) com a estabelecida no presente brabatho.

Na Tabela 7 estäo as doses de calcârio recomends das pelo método que está sendo atualmente vtilizado pelo jnstu tuto Agronónico. Esse método basedose no critério do aluminio trocavel juntamente com o critejto complementax, que procura ganantir os teores de Ca + Mg no solo aos valores de 2 ou 3

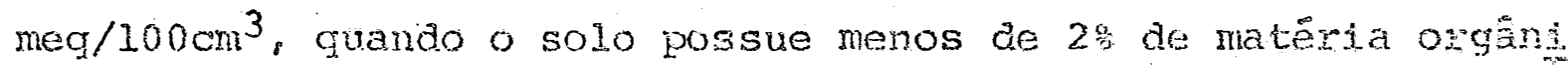
ca ou mais de $2 \%$, respectivanente. Pode-se observar que as do sagens gexalmente recomendadas são pequenas, devido principalmerice aos baisros teores de aluminio trocâvel observados nos so los do Estado de são Paulo. os valores de pH alcançados por esse mëtodo não ultrapassam o valor an 5,5, con exceçăo de soLos arenosos com baixos teores de matëria organica. Esses vaw loxes, correspondem aproximadamente aos riveis obtidos com 40 y 
Tabela 6. Necessiáade de calagem (1) calculada através da sa turação de bases, obtida pelo método do acetato de cälcio e pelo mẹtodo proposto, para trẹs niveis de calagem.

\begin{tabular}{|c|c|c|c|c|c|c|}
\hline \multirow[t]{3}{*}{ Amostra } & \multicolumn{6}{|c|}{ Saturação de } \\
\hline & \multicolumn{2}{|c|}{408} & \multicolumn{2}{|c|}{$60 \%$} & \multicolumn{2}{|c|}{$80 \%$} \\
\hline & $\mathrm{Ca}(\mathrm{OAC})_{2}$ & $\begin{array}{l}\text { Mécodo } \\
\text { proposto }\end{array}$ & $\mathrm{Ca}(\mathrm{OAC}) ?$ & $\begin{array}{c}\text { Método } \\
\text { proposto }\end{array}$ & $\mathrm{Ca}(\mathrm{OAC})_{2}$ & $\begin{array}{l}\text { Wetodo } \\
\text { proposto }\end{array}$ \\
\hline & $-\infty-\infty-\infty$ & $\ldots-\infty$ meql & $100 \mathrm{~cm}^{3}$ or & t tha $x$ & $20 \mathrm{~cm}-m$ & 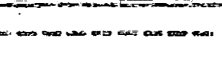 \\
\hline $\begin{array}{r}40501 \\
502 \\
503 \\
504 \\
505\end{array}$. & $\begin{array}{l}0,0 \\
0,2 \\
0,0 \\
0,0 \\
1,4\end{array}$ & $\begin{array}{l}0,0 \\
0,2 \\
0,0 \\
0,0 \\
I, 1 .\end{array}$ & $\begin{array}{l}0,5 \\
0,8 \\
1,6 \\
0,0 \\
3,3\end{array}$ & $\begin{array}{l}0,4 \\
0,8 \\
0,3 \\
0,0 \\
2,8\end{array}$ & $\begin{array}{l}1,6 \\
1,4 \\
4,9 \\
0,0 \\
5,3\end{array}$ & $\begin{array}{l}1,5 \\
1,5 \\
3,1 \\
0,0 \\
4,6\end{array}$ \\
\hline $\begin{array}{r}40506 \\
507 \\
508 \\
509 \\
510\end{array}$ & $\begin{array}{l}1,3 \\
4,9 \\
0,0 \\
1,9 \\
5,0\end{array}$ & $\begin{array}{l}1,3 \\
5,2 \\
0,0 \\
2,4 \\
4,8\end{array}$ & $\begin{array}{l}2,5 \\
6,5 \\
0,0 \\
3,1 \\
7,9\end{array}$ & $\begin{array}{l}2,5 \\
8,0 \\
0,0 \\
3,8 \\
7,6\end{array}$ & $\begin{array}{r}3,8 \\
8,8 \\
2,5 \\
4,3 \\
10,8\end{array}$ & $\begin{array}{r}3,8 \\
10,8 \\
1,1 \\
5,2 \\
10,3\end{array}$ \\
\hline $\begin{array}{r}40511 \\
512 \\
51.3 \\
514 \\
515\end{array}$ & $\begin{array}{r}2,5 \\
4,4 \\
11,2 \\
0,0 \\
0,0\end{array}$ & $\begin{array}{r}2,9 \\
6,0 \\
10,7 \\
0,0 \\
0,0\end{array}$ & $\begin{array}{r}4,5 \\
6,9 \\
17,0 \\
0,0 \\
0,0\end{array}$ & $\begin{array}{r}5, \pi \\
9,2 \\
16,3 \\
0,0 \\
0,0\end{array}$ & $\begin{array}{r}6,4 \\
9,3 \\
23,0 \\
1,0 \\
0,5\end{array}$ & $\begin{array}{r}7,3 \\
12,4 \\
22,0 \\
1,3 \\
0,5\end{array}$ \\
\hline $\begin{array}{r}40516 \\
517 \\
518 \\
519 \\
520\end{array}$ & $\begin{array}{l}0,0 \\
0,0 \\
3,0 \\
3,0 \\
0,0\end{array}$ & $\begin{array}{l}0,0 \\
0,0 \\
1,1 \\
1,0 \\
0,0\end{array}$ & $\begin{array}{l}0,5 \\
0,0 \\
1,9 \\
2,8 \\
1,0\end{array}$ & 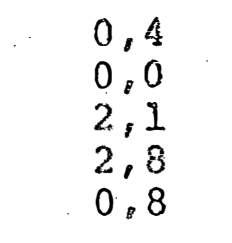 & $\begin{array}{l}1,7 \\
0,7 \\
2,9 \\
4,6 \\
2,8\end{array}$ & $\begin{array}{l}1,6 \\
0,7 \\
3,1 \\
4,6 \\
2,1\end{array}$ \\
\hline $\begin{array}{r}40521 \\
: 522 \\
523 \\
528 \\
525 \\
526\end{array}$ & $\begin{array}{l}0,0 \\
0,0 \\
1,9 \\
4,2 \\
2,9 \\
6,7\end{array}$ & $\begin{array}{l}0,0 \\
0,0 \\
2,2 \\
4,9 \\
1,6 \\
5,4\end{array}$ & $\begin{array}{r}1,7 \\
0,8 \\
3,2 \\
6,6 \\
7,8 \\
11,6\end{array}$ & $\begin{array}{l}1,7 \\
0,8 \\
3,6 \\
7,8 \\
5,8 \\
9,7\end{array}$ & $\begin{array}{r}3,5 \\
1,8 \\
4,6 \\
9,1 \\
12,6 \\
16,6\end{array}$ & $\begin{array}{r}2,5 \\
1,8 \\
5,1 \\
10,6 \\
10,0 \\
14,0\end{array}$ \\
\hline Media & 1,9 & 1,9 & 3,5 & 3,5 & 5,5 & 5,5 \\
\hline
\end{tabular}

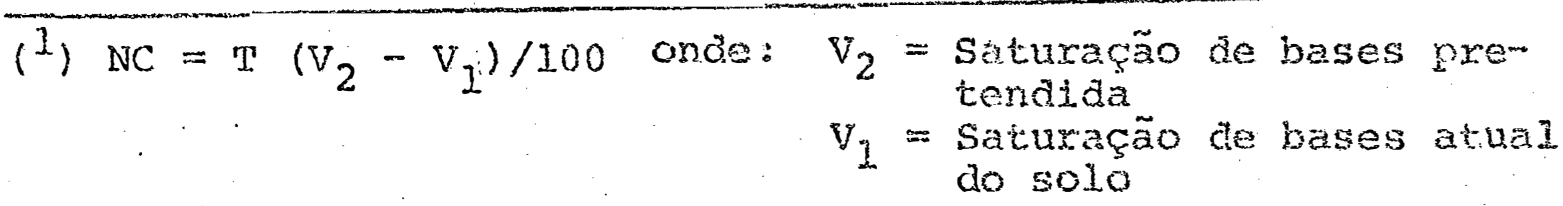


de saturação de bases pelo mẻtodo proposto (Tabela 6). Com os valores do $\mathrm{pH}_{\mathrm{SMP}}$ das amostras estudadas, obteve-se a recomendação de calagem diretamente pelo mëtodo SMP, utilizando-se para isso, as tabelas de RAIJ et alii.(1979) para o caso de São Paulo e a tabela do Estado do Rio Grande do Sul (BOHNEN et alii, 1971), sendo que os dados obtidos encontram-se na Tabela 7. As recomenđações para as amostras de nümeros 40513 e 40526 não foram incluĩdas no cälculo das médias porque são solos com capacidade tampão mujto elevada e, portan to, os valores do $\mathrm{pH}_{S M P}$ correspondentes ultrapassam o limile jnferior das tabelas utilizacias no câlculo das doses pelo mêt do SMP. Contudo, pode dizer com base na recomendação mẻdia que o método proposto é comparärel com o método SMP para o mes mo nîvel de calagem. Esses resultados, serviram para aferix a precisão do método desenvolvido, pois, a precisão do método SMP já foi anteriormente comprovada (KEENEY \& COREY, 1963; MCLEAN et alij, 1966; 1978; CATANI \& ALONSO, 1969 e TRAN a IIIEROP, 1981). Comparando-se as doses recomendadas pelo critë rio atual e pelo mëtodo proposto, observa-se que as recomendações desse ültimo, para 408 de saturação de bases (Tabela 6 ) são praticamente idênticas ăs do critërio atual. Jä a reconeñ dação para pH 6,0 que corresponde aproximaciamente a $74 \%$ da sai. turação de bases, proporciona un aumento mẻdio igual a três ve zes ao critërio atual. 
Tabela 7. Comparação entre a recomendação de calagem fełta pe lo mëtodo proposto, com o critêrto atualmente empre gado pelo Instituto Agronômico, e com o mëtodo SMP cálibrado para os Estados de são Paulo e Rio Grande do sul

\begin{tabular}{|c|c|c|c|c|c|}
\hline \multirow{3}{*}{$\begin{array}{l}\text { Amostra } \\
\text { NO }\end{array}$} & \multirow{3}{*}{$\begin{array}{c}\text { IAC } \\
\text { atual }\left({ }^{1}\right)\end{array}$} & \multicolumn{4}{|c|}{ Necessidade de calagem para pH 6,0} \\
\hline & & \multirow{2}{*}{$\begin{array}{l}\text { Método } \\
\text { proposto }(2)\end{array}$} & \multicolumn{3}{|c|}{ SMP } \\
\hline & & & São Paulo(3) & $R . G$. & do $\operatorname{sul}(4)$ \\
\hline & $-\infty-n$ & $-\infty \mathrm{meq} / 100 \mathrm{cr}$ & $m^{3}$ ou $t / h a x$ & $20 \mathrm{~cm}-$ & $m-\infty-\infty-\infty-\infty$ \\
\hline $\begin{array}{r}40501 \\
502 \\
503 \\
504 \\
505\end{array}$ & $\begin{array}{l}0,0 \\
3,0 \\
0,1 \\
0,0 \\
0,7\end{array}$ & $\begin{array}{l}1,2 \\
1,3 \\
2,2 \\
0,0 \\
\therefore, 0\end{array}$ & $\begin{array}{r}0,9 \\
0,0 \\
3,8 \\
0,0 \\
4,4\end{array}$ & & $\begin{array}{l}1,5 \\
0,0 \\
4,7 \\
0,0 \\
5,3\end{array}$ \\
\hline $\begin{array}{r}40506 \\
507 \\
508 \\
509 \\
510\end{array}$ & $\begin{array}{l}1,9 \\
3,4 \\
0,0 \\
1,8 \\
3,0\end{array}$ & $\begin{array}{r}3,4 \\
10,0 \\
0,1 \\
4,8 \\
9,5\end{array}$ & $\begin{array}{r}3,2 \\
10,5 \\
2,2 \\
4,4 \\
10,5\end{array}$ & 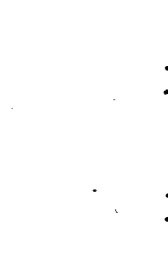 & $\begin{array}{r}4,2 \\
10,6 \\
3,2 \\
5,3 \\
10,6\end{array}$ \\
\hline $\begin{array}{r}40511 \\
512 \\
513 \\
514 \\
515\end{array}$ & $\begin{array}{l}1,8 \\
3,3 \\
6,4 \\
0,1 \\
0,0\end{array}$ & $\begin{array}{c}6,6 \\
11,5 \\
20,3(5) \\
0,8 \\
0,4\end{array}$ & $\begin{array}{r}7,6 \\
11,6 \\
-\infty \\
0,9 \\
0,0\end{array}$ & & \begin{tabular}{r}
8,1 \\
11,5 \\
\hdashline 1,5 \\
0,0
\end{tabular} \\
\hline $\begin{array}{r}40516 \\
517 \\
518 \\
519 \\
520\end{array}$ & $\begin{array}{l}0,0 \\
0,0 \\
1,2 \\
0,8 \\
0,1\end{array}$ & $\begin{array}{l}1,2 \\
0,3 \\
2,8 \\
4 ; 1 \\
1,9\end{array}$ & $\begin{array}{l}0,9 \\
0,3 \\
2,2 \\
4,4 \\
2,2\end{array}$ & & $\begin{array}{l}1,5 \\
0,0 \\
3,2 \\
5,3 \\
3,2\end{array}$ \\
\hline $\begin{array}{r}40521 \\
522 \\
523 \\
524 \\
525 \\
526\end{array}$ & $\begin{array}{l}0,3 \\
0,1 \\
1,5 \\
2,7 \\
1,0 \\
3,7\end{array}$ & $\begin{array}{c}3,0 \\
1,5 \\
4,7 \\
9,9 \\
8,7 \\
12,6(5)\end{array}$ & $\begin{array}{r}3,2 \\
0,9 \\
4,4 \\
10,5 \\
10,5 \\
-\end{array}$ & & $\begin{array}{r}4,2 \\
1,5 \\
5,3 \\
10,6 \\
10,6 \\
--\end{array}$ \\
\hline Média & 1,3 & 3,9 & 4,1 & & 4,7 \\
\hline
\end{tabular}

(1) Al $\times 1,5$ ou $\mathrm{Ca}+\mathrm{Mg}=2$ ou $3 \mathrm{meq} / 100 \mathrm{~cm}^{3}$, conforme o teor $\mathrm{M} .0$.

(2) Corresponde à 748 de saturação de bases

(3) Obtida com o pHSMP, através da tabela de RAIJ et ali1(1979).

(4) Obtida com o pHSMP, atravês da tabela do Rio Grande do SuI

(5) Essas amostras não foram incluías no cálculo da média 
5. CONCLUSÕES

Com base nos resultados obtidos no presente estu do, conclue-se que:

1. A capacidade de troca de cátions dos solos do Estado de são paulo depende principalmente da fração orgânj.ca desses solos, enquanto que, a contribuição da fração mineral é modesta.

2. A acidez potencial $(H+A I)$ desses solos oriunda principalmente da dissociação de grupos funcionais da matêria orgänjica, uma vez que, os teores de alumínio trocável são baixos, con um valor mêdio observado de $0,83 \mathrm{meq} / 100 \mathrm{~cm}^{3}$ de terra e sempre bem menores do que os teores de hidrogênio.

3. En torno de pH 5,4 para a determinação em água ou pH 4,8 para a determinação em solução $\mathrm{CaCl}_{2} 0,01 \mathrm{M}$ a saturação de alumínio nesses solos è igual a zero, ou o aluminio trocävel è totalmente neutralizado. por essa xazão, o cri tërio de recomendação de calagem baseado no teor de alumínio 
trocâvel não permite o cảlculo da calagem para nĩveis superiores a esses valores de pḦ, perdendo-se, portanto, o controle da reação do solo.

4: E possível a determinação de $\mathrm{H}+\mathrm{Al}$ no solo atravês dâ leitura do pH de equilỉbrio da solução tampão SMP com o solo. Esse método alëm de ser mais prático e rápido do que o da extração com solução normal de acetato de cálcio a $\mathrm{pH} 7,0$, possue ainda melhor reprodutibilidade.

5. Tudo indica que a correlação entre $\circ \mathrm{pH}$ e sa turação de bases do solo é bastante consistente para as condições dos solos brasileiros, e mais especificamente para as con dições des solos do Estrado de são Paulo.

6. A correlação entre o pH e saturação de bases do solo torna-se mais estreita com o uso do $\mathrm{pH}$ em $\mathrm{CaCl}_{2}$ 0,01M. Isso demonstra maior precisão na determinação do pH, em relação a determinação do pH em ăgua.

7. o mëtodo de recomendação de calagem desenvo! vi.do no presente trabalho, fornece resultaios idênticios ao mëtodo da extração com acetato de cálcio proposto por CATANI \& GALIo (1955), porēm, é mais" adaptado às condições de laboratôrios de rotina que realizam grande nümero de anälises diaria mente.

8. o método atualmente empregado para a recomen dação de calagem no Estaajo de são Paulo, que é baseado no critério do alumínio trocāvel e cālcio mais mágnẹsio, recomenda 
geralmente pouco calcärio, atingindo somente o nível de $40 \%$ de saturação em bases do solo. 
6. LITERATURA CITADA

ADAIS, F. e C.E. EVANS。 1962. A rapid method for measuring lime requirement. Soil Sc.Soc. Amer. Eroc. Madison, 26: $355-357$.

ARAUJO, J.E.G. I949. O aluminio trocāvel, possivel causa do crestamento do trigo. In: Anais da 2a. Reunião Brasileira. de Ciência do Solo, Rio de Janeiro, p. 328-337.

BHUMBLA, D.R. e E.O. MCLEAN. 1965. Aluminium in soils: VI. Changes in $\mathrm{pH}$ dependent acidity, cation exchange capacity and extractable aluminium with addition of lime to acid. surface sojls. Soil Sci.Soc. Amer. Proc. Madison, 29:370-374 .

BOHNEN, H., A.E. LUDWICK e S.J.VOLKWEISS. 1971. Recomendações de adubo e calcário para os solos e culturas do Rio Grande do Sul. Universidade Federal do Rio Grande do Sul , Faculdade de Agronomia, 38p. (Boletim ng 2). 
BRADFIELD, R. 1923. The nature of the acidity of colloidal clay of acid soils. J.Amer. Chem. Soc. Easton, 45:26692678 .

BRADFIELD, R. 1942. Calcium in the soil: I. Physico-chemical relations. Soil.Sci.Soc. Amer. Proc. Madison, 6:8-15. BRASIL. 1960。 Ministērio de Agricultura. Centro Nacional de Ensino e Pesquisas Agronômicas. Comissão de Solos, 1960. Levantamento de reconhecimento dos solos do Estado de são PauIo, Rio de Janeiro, $634 \mathrm{p}$.

BROWN; I.C. 1943. A rapid method of determining exchangeable hidrogen and total exchangeable bases of soils. Soij. Sci., Baltimore, 56:353-357。

CAMARGO, O.A. e B. VAN RAIJ。 1975. Relações entxe o alumínio trocävel, bases trocåveis e pH em solos.. In: Anais do XVV Congresso Brasileiro de Ciência do Solo, Campinas, p.95-10l. CASTRO, A.F., W.O. BARRETO, e M.I.A. ANASTÁCIO. 1972. Coriela ção entre o pH e saturação de bases de algiuns solos brasile ros. Pesq. Agropec. Bras., Serv. Agron. Rio de Janeiro, 7: $9-17$

CATANI, R.A. e J.R. GALLO. 1955., Avaliação da exigência ce calcärio dos solos do Estado de são Paulo mediante a correla ção entre o pH e saturação de bases. Rev. da Agricultura, Ijracicaba, 30:49-60.

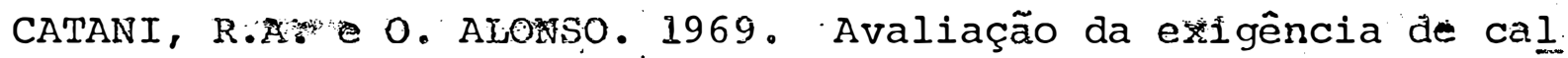
cärio do solo. Anais da Esc. Sup. Agric. "Luiz de Quefroz". Pixacicaba, 26:141-156. 
CATE, R. 1965. Sugestões para adubação com base na anālise de solo. North Carolina State University. International, Soil Testing Project, Raleigh $16 \mathrm{p}$.

CHERNOV, V.A. 1947. The nature of soil acidity: Trad., Madison, Soil Science Society of America, 169p.

CHERNOV, V.A., N.F. BELIAEVA E V.C. MAXIMOVA. 1956. Rate of replacement of hidrogen by aluminum ion in clays. Soviet Soil Sci., Moscou, 110:849-851.

CHERIOV, V.A. 1959. On the genesis of the exchangeable aluminium in soils. Soviet Soil Sci., Moscou, 113:25-33. COLEMAN, N.T., D.E. WILLIAMS, T.R. NIELSEN e H. JENNY. 1951. On the validity of interpretations of potenciometrically measured of soil pH. Soil Scj. Soc. Amer. Proc., Madison, $15: 106-110$.

COLEMAN, N.T. e R.E. HARWARD. 1953. The - heats of neutralization of acid clays and cation exchange. resins. J. Amer. Chen. Soc.p Easton, 75:6045-6046.

COLEMAN, N.T. e A. MEHLICH。 1957. The chemistry of soil pH. In: USDA. The yearbook of Agriculture, Washington, p.72-79. COIEMAN, N.T.. E.J. KAMPRATH e S.B. WEED. 1958. Liming. Advance Agron., 10:475-522.

COLEMAN, N.T., S.B. WEED e R.J. MCCRACKEN. 1959. Cationexchange capcity and exchangeable cations in Piedmont soils of North Carolina. Soil Sci. Soc. Amer. Proe., Madison, 23: $146-149$.

COLEMAN, N.T. E D. CRAIG. 1961. The spontaneous alteration of hydrogen clay. Soil Sci.., Baltimore, 91:14-18. 
COLEMAN, N.T., G.W. THOMAS, F.H. LeYOUX e G. BREDELL. 1964. Salt exchangeable and titrateable acidity. in bentonitesesquioxide mixture. Soil Sci. Soc. Amer. Proc., Madison, 28: $35-37$.

COLIINS, J.B., E.P. WHITESIDE e C.E. CRESS. 1970。 Seasonal variability of $\mathrm{pH}$ and lime requirement in several Southexn Michigan soils when measured in different ways. Soil Sci. Soc. Amer. Proc., Madison, 34:56-61.

COMBEAU, A., C. OLIAT e P. QUANTIN. 1961. Observações sobre certas caracteristicas dos solos ferraliticos. Fertilité, Paris, 13:27-40.

DAIKUHARA, G. 1914. About acid minerals. Imp. Agr. Exp. Stat, Japan, p.1-40 (Bull, no 2).

DAVIES, B.E. 1971. A statistical comparison of $\mathrm{pH}$ values of some English soils after measurement in both vater and 0,01M calcium chloride. Soll Sci. Soc. Amex, Proc., Madison, 35 : $551-552$.

EPAMIG. Comissão de Fertilidade do Solo do Estado de Minas Ge rais. 1978. Tabelas de recomendação de adubação e calagem. 3a. aproximação, Belo Horizonte, $80 \mathrm{p}$. FASSBENDER, H.W. 1975. Química de suelos. Turrialba, Costa Rica, Editora de la Cruz. 390p. (Sex. Libros y Materiales Educativos).

FREITAS, I.M.M., F.P. PRATT e L. VETTORI. 1968. Testes sápidos para estimar a necessidade de calcârio em alguns solos do Estado de são Paulo. Pesq. Agropec. Bras., Serv. Agron., Rio de Janeiro, 3 : 159-164. 
HARWARD, M.E. E N.T. COLFMAN, 1954. Some properties of H and $\lambda z$ clays and exchange resins. Sojl Sci.p Baltimore, 79 : $181-188$

HISGINK, D.J. 1924. Bàse exchange in soils. Faraday Soc., Genexal discussion, Londres, 55l-560.

EsU, P.H. e C.I.RICH. 1960。 Aluminum Eixation in a synthetic cation exchanger. Soil Sci, Soce Amer. Procor Madison, $24:$ $21-25$

JACKSON, M.I. 1960. Structural of hydroniun in layes silicates during soil genesis. In: VII Intern. Congress of Soil Science, Madison, p. 445-455, V.2.

JACKSON, M.I. 1963. Aluminum bonding in soils: A unfying principle in soil science. Soil Sai Soc, Aner. Proc. Madison, 27:i-10.

JONES, C.H. I913. Method Of daterinining the lime requirement of soils. Amer. Fert.p Fhiladelphia, $39: 28-29$.

KMNRETH，E。J. 1970. Exchange ajuminum as a criterion for Innirg leached mineral soils. Soil Sci. Soc. Amer. Proc. Madison, $34: 252-254$.

WEENGY, D.R = e R.B. COREY. 1963. Factors affecting the lime requitement of nisconsin soils. Soil Gei. Soc. Ames. Froc. viadison: $27: 277-230$.

rov. P.F. 1955. The role of aluminuin the thistions of bentonite. SoiI Sci. Sod. Arex. Proe.Madson, 19:135-139. Whanoma, E. ig75. Manual de cuinica agricoia: nutricão de plantas efertilidade do solo. Säo Pallo. Ed. Fgronontica Ce xe $\approx$. 528 . 
MCLEAN, E.O., H.E.SHOEMAKER e W.R. HOURIGAN。 1960。 SOME effects of aluminum on iime requirement test of soils. In: VII International Congress of Soil Science. Madison, Wisconsin, p.112-151, V.2。

MCLEAN, E.O., D.C. REICOSKY e C. IAKSHANAN, 1965. Aluminum in soils. VII. Interrelationships or organic matter, liming and extractable aluminum with "permanent charge" ( $\mathrm{KCl})$ and pH-dependent cation-exchange capacity of surface soils. Soil Sci. Soc. Amer. Proc. Mađison, 29:374-378.

MCLEAN, E.O., S.W. DUMFORD \& F. CORONEL. 1966. A comparison of several methods of determining lime requirements of soils. Soil Sci.Soc. Amer, Proc. Madison, 30:26-30. MCIJEAN, E.O., D.J. ECKERT, G.Y. REDDY e J.F。 TRAIERWEILER。 1978. An improved SMp lime requirement method incorporating double-buffer and quick-test features. Soil Sci. Soc.Am.J. Madison, $42: 311-316$ 。

MEHLICH, A. 1942. Base unsaturation and $\mathrm{pH}$ in relation to soil differences. Soil Sci. Soc. Amer. Proc. Madison, 6: $150-156$.

MEHLICH, A。 1943. I'ke significance of percentage base saturation and $\mathrm{pH}$ in relation to soil differences. Soil Sci. Soc. Amer, Proc. Madison, 7:167-174. MERKLE, F.G. 1934. Base exchange studies on the Pennsylvania Jordan field plots. Soil Sci. Baltimore, 38:37-64. 
PAIVA NETTO, J.E., R.A. CATANT, M.S. QUEIROZ E A. KÜPPER. 1947. Contribuição ao estudo dos mêtodos analiticos e de extração para a caracterização quimica dos solos do Estado de são Paú 10. In: Anais da la. Reunião Brasileira de Ciência do Solo, Rio de Janeiro, $p .79 \cdots 108$.

PARKR, F.W. 1929. The determination of exchangeable hidrogen in soils. J. Amer. Soc. Agron. Madison, 21:1030-1039.

PAVER, H. e C.E. MARSHALI. 1934. The role of aluminium in the reactions of the clays. I. Soc. Chem. Ind. Londres, 53:750 -760 .

PEECH, M. e W.F.MCDEVI'. 1951. Discussion of the paper on the validity of interpretations of potenciometrically measured soil pH, by COLEMAN et alii. Soll Sci. Soc. Amer. Proc. Madison, 15:112-114.

PEECH, M. 1965. Hydrogen-ion activity. In: BLACK, C.A. ed. Methods of soil analysis. Madison, Am, Soc.Agron, p.914926.

PIONKE, H.B. e R.B. COREY, 1967. Relation between acidic aluminum and soil pH, clay and organic matter. Soil Sci.Soc. Amer.Proc. Madison, 31:749-752:

PRATT, P.F.- E.L BAIR. 1961. A comparison of three reagents for the extraction of aluminum from soils. Soil Sci. Baltimore, $91: 357-359$.

QUAGGIO, J.A. e B.VAN RAIJ. 1979. Comparação de mëtodos rạp̣i dos para a determinação da matêria orgānica em solos. R.bras. Cl do solo. Campinas, 3:184-187. 
RAGLAND, J.L. e N.T. COLERIAN. 1960. The hydrolysis of aluminum salts in clay and soil systerns. Soil sci. Soc. Aner. Proc. Madison, 24:457-460.

REIJ, B.VAN E M.T.D. SACCHETTO. 1968. Comelnibes entre o pH e o srau de saturação de bases nor solos com horjzonte B. vex tural e horizonte B latossólico. Bragantia, Campinas 27: $193-200$

RAIJ, B.VAN. 1969. A capacidade de troca de cătions das frações orgânica e mineral em solos. Bragantia. Campinas $\underline{2}$ : 85-112.

RAIJ, B.VAIJ, M.A.T. ZULIO. 1977. Mëtodos de änälise de solc. Instituto Agronômico. Campinas, 16p. (Cirular, 63). RAIJ, B.VAN, H. CANTIAREISLA e M.A.T. ZULLO. 1979. O método tampão SMP para a determinação dä neciessiaade de calrageñ de solos do Estado de São Eaulo. Bragantia. Canpinas, 38:5769.

RICH, C.I. 'e S.S. OBENSHAIN. 1955. ChemicaI and clay mineral properties of a Red-yellow Podzolic soil derived from mica schist. Soil Sci. Soc. Amer. Proc. Madison, 19:334-339. RICH, C.I. 1960. Aluminum in interlayers of vermicuitite. Soil Sci. Soc. Amer. Proc., Madison, 24:25-32. SCHOPIELD, R.K. 1949. Effect of pli on electric charges carried by clay particles. J.Soij. Sci. Londres, J.j-8. SCHOPIELD, P.K. Q A.W. 'RAYLOR. 1354. The lydrojysis of a)uininum salt solutions. J. Chem! Soc. Iondres, $28: 4445-$ 4418 
SCHOFIELD, R.K. E A.W. TAYLOR. 1955. The measurement of soil pH. Soll Sci. Soc, Amer. Proc. Madison. 19:164-j67. SCEWERTMANN, V. e M.L。 JACRSON. 1964. Influence of hyaroxy aluminum ions on pï titrations curvas of hydroniurimaluninum daps. Soil Sci. Soc. Amer. Proc. Madison, 28:179-182. SHOENAKER, H.E., E.O. MCTHAN E P.T. PRATT. I96I. Buffer methods for determining lime reruirement of sois w with appreciable amounts of extractable aluminum. Soll Sci. Soo. Amer. Proc = Madison, 25:274-277.

SNEDECOR, G.W. A W.G. COCHRALi. 1976. Statistical methods.

6 ed. Ames, Iowa State university Press. $593 \mathrm{p}$. ThIN, T.S. e V.VAN IIBROY. 198I. Fvaluation and improvement of buffer lime requirement methods. Soil Sci. Baltimore $131: 1.78-188$

WGETER, P, i932. Dix katjonen-und wasserhaushalt des mineralboden. Ber]in, Julius Springer, 336p.

VAGRter, P. is56. Principios do câlculo do fornecinento dos sølos de nutrientes e da adubação racional. Instituto Agrom nómico. Campinas, p.J.8. mim.

VEITCF, F.P. 1902. The estimation of soil acidity and Jime requirement of sojis. I. Amer. Chem. Soc., Easton, 24:1120 -1.128 .

VETTCH, F.P. 1904, Comparison of methods for estimation of soil acidity. J. Imer. Chem. Soc. Easton, 26:637-642. VERDADE, F.C. 1956. Influência da matêria orgânica na capaci. dade de troca de cátions do solo. Aragantia. Campinas, $15:$ $35-42$ 
VETTORI, L: 1948. Determinaçäo da necessidade de cal dos solos. Instituto de Quínica Agrícola. Rio de Janeiro, 1.9p. (Boletim, 7).

VETTORI, L. 1969. Mêtođos de anälise do solo. Mỉnistërio da Agricultura. Equipe de Pedologia e Fertilidade do Solo. Rio de Janeiro, 24p. (Boletim, 7).

WHEELER, H.J., B.I. HARTWELL e SARGENT, C.L. 1900.' Chemical rethois for ascertaining the Jime requirement of soils. Rhode Island. Rhode Island Agric. Exp. Stat. 65-87p. (Bull. 62).

WOODRUFE, C.M. 1948. Testing soils for lime requirement by means of a buffered solution and the giass electrode. SoiI Sci. Baltimore, 66:53-63.

YUAN, T.I. 1974. A double buffer method for the determination of lime requirement of acid soils. Soil Sci. Soc. Amer. Froc Madison, 38:437-440.

YUAN, T.L. 1976. Anomaly and modification of pH acidity relationship in the double buffer method for lime requirement determination. Soil Sei. Soc. Am. J. Madison, 40:800-803. 